Review

\title{
Recent Advances in Second Generation Ethanol Production by Thermophilic Bacteria
}

\section{Sean Michael Scully and Johann Orlygsson*}

Faculty of Natural Resource Sciences, University of Akureyri, Borgir, Nordurslod 2, IS-600 Akureyri, Iceland; E-Mail: scully@unak.is

* Author to whom correspondence should be addressed; E-Mail: jorlygs@unak.is; Tel.: +354-460-8051; Fax: +354-460-8998.

Academic Editor: Dimitris S. Argyropoulos

Received: 16 October 2014 / Accepted: 5 December 2014 / Published: 24 December 2014

\begin{abstract}
There is an increased interest in using thermophilic bacteria for the production of bioethanol from complex lignocellulosic biomass due to their higher operating temperatures and broad substrate range. This review focuses upon the main genera of thermophilic anaerobes known to produce ethanol, their physiology, and the relevance of various environmental factors on ethanol yields including the partial pressure of hydrogen, ethanol tolerance, $\mathrm{pH}$ and substrate inhibition. Additionally, recent development in evolutionary adaptation and genetic engineering of thermophilic bacteria is highlighted. Recent developments in advanced process techniques used for ethanol production are reviewed with an emphasis on the advantages of using thermophilic bacteria in process strategies including separate saccharification and fermentation, simultaneous saccharification and fermentation (SSF), and consolidated bioprocessing (CBP).
\end{abstract}

Keywords: bioethanol; thermophiles; second generation biofuel; genetic engineering; consolidated processes

\section{Introduction}

The increasing demand for sustainable biofuels is driving the need for feasible bio-refineries capable of utilizing highly renewable and environmentally friendly feedstock's to produce high-volume biofuels. The rise in biofuel demand largely stems from targets set by governments in response to an increasing 
awareness of climate change, finite petroleum resources, and geo-political uncertainty while addressing the ever increasing energy demand of industrialized society. Thus, the need for sustainable low-cost, high-volume alternative energy carriers, such as bioethanol, produced from renewable feedstocks is apparent. For example, a target set by the European Commission necessitates that $20 \%$ of energy production by 2020 must be from renewable sources, energy efficiency must increase by $20 \%$ while greenhouse gases must decrease by $20 \%$ [1,2]. The worldwide production of bioethanol has increased from 48.0 billion liters in 2007 to 88.7 billion liters in 2013, with the largest producers being the United States and Brazil [3]. The vast majority of bioethanol produced to date is so-called first generation bioethanol generated from simple substrates including starch (from corn) and sucrose (from sugarcane and sugarbeet). Despite the success of first generation bioethanol production, there is growing concern over the feedstocks used as they are often food crops leading to biofuel production directly competing with food consumption thus neccesstating an increase in food prices; this is often refered to as the "food versus fuel" debate [4,5]. Additionally, there is concern regarding the negative impact on agricultural areas when crops are harvested soley for their energy value [4].

Second generation biofuels address these concerns as they are derived from non-food (lignocellulosic) biomass demonstrating a move towards a more sustainable biofuel production that meets the demand for bioethanol using raw materials and does not compete with food. Lignocellulosic biomass is often an agricultural by-product such as straw produced from wheat or corn [4]. However, second generation bioethanol production is not without obstacles; lignocellulosic biomass are often recalcitrant due to the lignin sheath and the highly crystalline structure of cellulose which is tightly packed and stabilized with a network of intra- and inter-molecular hydrogen bonds between parallel strands [6]. Additionally, lignocellulose contains hemicelluloses, which are comprised of polyhetereosaccharides including hexoses, pentoses, galactouronic sugars, and other sugar derivatives [7]. As such, second generation bioethanol production requires extensive and costly chemical or physical pretreatment in addition to enzymatic treatment processes which negatively influences its industrial feasability and has proven to be a major obstacle for large scale production $[4,5]$.

If bioethanol produced from lignocellulosic biomass is to become economically feasable, sustainable, and competitive with petroleum-derived fuels, several key physiological and process challenges need to be overcomed. This includes the integration of process steps into consolidated processes, achieving higher ethanol titers, as well as avoiding possible inhibition by sugar derivatives that are produced during various pretreatment and enzymatic hydrolysis processes of complex biomass, and the genetic manipulation of ethanologens. At present, the majority of bioethanol is produced using mesophilic organisms despite the inherent advantages of using thermophilic ethanologens which could potentailly overcome many of these obstacles.

This review focuses on thermophilic aneaerobes, their physiology, ethanol production capacity, process advances, and recent advances in the genetic modification of thermophilic ethanologens with a particular emphasis on second generation bioethanol production and the ammenability of thermophiles for consolidated processes. 


\section{Ethanol Production from Biomass}

\subsection{Difference between First and Second Generation Ethanol Production}

First generation bioethanol is generated from homogenous substrates, including starch and sucrose. Typically, this has been accomplished by using high-yield mesophilic ethanologens such as the yeast Saccharomyces cerevisae and, to a lesser extent, the bacterium Zymomonas mobilis. While these mesophiles demonstrate near-theoretical ethanol yields, high ethanol tolerance, and have a long history of large-scale ethanol production, their use for bioethanol production from lignocellulosic biomass is limited due to the narrow substrate spectra of the wild type strains.

Second generation ethanol production from more complex (lignocellulosic) biomass has yet to achieve industrial-scale success. Lignocellulose is composed of three different components: cellulose, hemicellulose, and lignin [4,7]. Hemicellulose and lignin are tightly embedded in the plant material. Before utilization of such biomass, the lignin needs to be removed and the sugar polymers released in order to make them accessible for the subsequent hydrolytic/enzymatic steps. This extra pretreatment step is the main difference between the utilization of simple biomass (starch and sugars) compared to complex biomass together with the fact that the sugar pool released in the latter is more heterogeneous as compared with first generation substrates $[4,5]$.

In order to meet the increased demand for second generation ethanol production, the genetic modification of $S$. cerevisae and Z. mobilis and the use of microbes with much broader substrate spectra are needed for a complete utilization of the various sugars present in the biomass. The interest in the use of thermophiles for second generation production was first put forward after the oil crisis in the 1980s and has recently received increased attention in the past decade.

\subsection{Comparison between Mesophilic and Thermophilic Microbes Producing Ethanol}

For the fermentative production of ethanol from biomass to be commercially successful, several key processes and organisms need to be considered [4,5,8-10]. The points below highlight the requirements needed from two points of view: the physiological properties of the ethanologen used and process requirements.

Organism requirements:

- Minimal by-product formation;

- High productivity $(>1 \mathrm{~g} / \mathrm{L} / \mathrm{h})$;

- GRAS-status;

- Broad tolerance to environmental conditions;

- High ethanol tolerance;

- Broad substrate spectra;

- No "glucose effect";

- High cellulolytic activity;

- Tolerant to inhibitory compounds;

- Tolerate high solid and substrate loadings;

- Simple nutritional needs; 
- Low biomass production;

- Ease of genetic manipulation.

Process requirements:

- $>90 \%$ of theoretical yield;

- High ethanol titers (>5\% (v/v));

- Minimum number of process steps;

- Minimal process cooling;

- Recyclable cells;

- Co-fermentation of substrates;

- Limited or no pretreatment;

- Limited or no pretreatment.

At present, there is no single organism that possesses all these features. While genetic manipulation is a valuable tool, it has yielded only modest improvements for ethanologens and these techniques rarely yield stable transformants $[11,12]$. Z. mobilis and S. cerevisae are very powerful ethanol producers but with limited substrate spectrum, only degrading glucose, fructose, and sucrose to ethanol, acetate, lactic acid, and so forth. Furthermore, Z. mobilis uses a more complex degradation pathway (Entner Doudoroff) which leads to the formation of unwanted end-products during degradation of fructose and sucrose [13].

Thermophilic bacteria have many properties making them suitable for second generation ethanol production $[5,10]$. Thermophiles degrade a much wider range of carbohydrates as compared with both $S$. cerevisae and $Z$. mobilis and their cultivation does not require extensive mixing, cooling, or heating of the fermentation vessel. Additionally, direct ethanol recovery from the fermentation broth is possible by in situ vacuum distillation. Apart for the broad operating temperature ranges, thermophiles often tolerate extremes of $\mathrm{pH}$ and salt concentrations during fermentation while having low nutritional requirements [5]. Also, thermophiles are generally recognized as safe (GRAS) with all known thermophiles being classified in the lowest microbial risk class. From a process perspective, mixing operations are easier at elevated temperatures due to reduced viscosity and increased substrate loadings [14]. Furthermore, mass transfer rates are higher at increased temperatures and the risk of mesophilic contamination is lower at higher process temperatures [14].

\section{Thermophilic Ethanol Producers}

The interest in the biotechnological potential of thermophilic anaerobes has increased due to their ability to produce ethanol from a broad range of substrates and the ability of some species to degrade biopolymers such as cellulose, starch, and hemicelluloses including xylan [5,10]. Microorganisms are categorized according to their optimal $\left(T_{\mathrm{opt}}\right)$ and maximal $\left(T_{\max }\right)$ growth temperatures. Moderate thermophiles have $T_{\text {opt }}$ values ranging from $50{ }^{\circ} \mathrm{C}$ to $64{ }^{\circ} \mathrm{C}$, extreme thermophiles between $65{ }^{\circ} \mathrm{C}$ and $79^{\circ} \mathrm{C}$, while hyperthermophiles grow optimally at greater than $80{ }^{\circ} \mathrm{C}[15]$.

More than 300 species of thermophilic anaerobic bacteria have been isolated and described as of 2008 [15]. Their habitats include geothermal areas [16-18], deep sea vents [19], river bank sediments [20], and artificial habitats such as self-heated compost piles [21], municipal solid waste or sewage sludge [22], 
oil wells [23], and thermally treated foods [24]. This suggests that thermophilic anaerobes are somewhat ubiquitous in nature. Most known thermophilic species are obligate or facultative anaerobes due to the low oxygen concentrations of their native geothermal environments [25].

Species of highly ethanologenic thermophilic anaerobes are typically members of the genera Clostridium, Caldanaerobacter, Thermoanaerobacter, or Thermoanaerobacterium [5,26,27] (Table 1) although there are thermophilic members of Bacillus, Geobacillus, Paenibacillus, and Caloramator that also produce ethanol $[21,27,28]$. The physiology and ethanol production potential of species within most genera has not been widely investigated; typically studies have focused upon one or two members within each genus.

Clostridium is a large and highly diverse genus within the class Clostridia (family Clostridiaceae, order Clostridiales) and currently contains more than 200 validly described species of which only about 15 are thermophilic [29,30]. Most thermophilic members of the genus have a $T_{\text {opt }}$ in the range of $45-65{ }^{\circ} \mathrm{C}$. Clostridium species are strictly anaerobic and can typically be isolated from a broad range of nutrient-rich habitats [31]. A number of species have been noted to hydrolyze biopolymers in addition to fermentation, making them target of extensive research on biofuel production from complex biomass $[32,33]$. The most exploited thermophilic ethanologenic Clostridium species is C. thermocellum. This bacterium degrades crystalline cellulose using a complex set of hydrolytic enzymes termed a cellulosome [6]. Several other members of the genus also express this enzyme complex such as C. acetobutylicum [34,35] and C. cellulovorans [36]. Yields of ethanol by Clostridium species are often relatively moderate and vary a great deal depending on environmental conditions. Clostridium thermocellum for example has been described to produce acetate as the main end product but can shift to be highly ethanologenic [37].

The genera Thermoanaerobacterium, Caldanaerobius, Thermoanaerobacter, and Caldanaerobacter were originally classified within the genus Clostridium due to their close phylogenetic relationship and similar physiological properties. The genus Thermoanaerobacterium is comprised exclusively of thermophilic anaerobes which fall within Cluster V of Clostridia [38]. The genus currently consists of nine species and $T$. thermosulfurigenes is the genus type species [39]. Strains within Thermoanaerobacterium are typically amylolytic and xylanolytic with a $T_{\text {opt }}$ between $55^{\circ} \mathrm{C}$ and $65{ }^{\circ} \mathrm{C}$. Thermoanaerobacterium strains have been isolated from geothermal areas and from thermally treated foods $[24,40,41]$. These bacteria convert a broad range of carbohydrates to predominately ethanol and acetate although lactate formation does occur. Considerable work has been carried out using Thermoanaerobacterium species on ethanol production with various yields. Highest yield observed were $1.5 \mathrm{~mol}$ ethanol/mol glucose by Thermonaaerobacterium AK17 at low glucose concentrations but lowered to less than $1.0 \mathrm{~mol}$ ethanol/mol glucose at increased initial substrate loadings [42]. 
Table 1. Overview of representative highly ethanologenic anaerobic thermophilic bacteria (modified from [26]).

\begin{tabular}{|c|c|c|c|c|c|c|c|c|}
\hline Microorganism & $\begin{array}{c}\text { Selected substrate } \\
\text { spectra }\end{array}$ & $\begin{array}{c}\text { Polymer } \\
\text { degrading ability }\end{array}$ & $\begin{array}{l}\text { Ethanol } \\
\text { tolerance }\end{array}$ & $\begin{array}{l}\text { Inhibitor } \\
\text { tolerance }\end{array}$ & $\begin{array}{c}\text { Fermentation } \\
\text { products } \\
\end{array}$ & $\begin{array}{c}\text { Max ethanol yields } \\
\text { (mol/mol sugar) }\end{array}$ & $\begin{array}{l}T_{\text {opt }} \\
\left({ }^{\circ} \mathrm{C}\right)\end{array}$ & References \\
\hline Caloramator boliviensis & $\mathrm{g}$, gal, man, $\mathrm{x}, \mathrm{a}, \mathrm{cel}$, suc & $\mathrm{X}$ & ND & ND & $\mathrm{E}, \mathrm{A}, \mathrm{L}, \mathrm{P}, \mathrm{H}$ & $1.53(\mathrm{x})$ & 60 & {$[28,43]$} \\
\hline Clostridium thermocellum & $\mathrm{g} *$, cel & $\mathrm{C}$ & $4 \%-5 \%$ & ND & $\mathrm{E}, \mathrm{A}, \mathrm{L}, \mathrm{F}, \mathrm{H}$ & $1.53(\mathrm{~g})$ & 60 & {$[44-47]$} \\
\hline Clostridium AK1 & $\mathrm{g}$, gal, man, $\mathrm{x}$, suc & $\mathrm{S}, \mathrm{X}, \mathrm{P}$ & ND & ND & $\mathrm{E}, \mathrm{A}, \mathrm{H}$ & $1.50(\mathrm{~g}), 0.85(\mathrm{x})$ & 50 & [48] \\
\hline Thermoanaerobacterium saccharolyticum & $\mathrm{g}$, gal, man, $\mathrm{x}, \mathrm{a}$, cel, suc & S, $\mathrm{X}$ & NR & NR & $\mathrm{E}, \mathrm{A}, \mathrm{L}, \mathrm{H}$ & $1.18(\mathrm{x})$ & 60 & {$[40,49]$} \\
\hline Thermoanaerobacterium AK17 & $\mathrm{g}$, gal, man, $\mathrm{x}, \mathrm{a}, \mathrm{suc}$ & $\mathrm{P}$ & $3.2 \%$ & $\begin{array}{c}4 \mathrm{~g} / \mathrm{L} \mathrm{FF} \\
6 \mathrm{~g} / \mathrm{L} \mathrm{HMF}\end{array}$ & $\mathrm{E}, \mathrm{A}, \mathrm{H}$ & $1.50(\mathrm{~g}), 1.33(\mathrm{x})$ & 60 & {$[42,50]$} \\
\hline Thermoanaerobacter ethanolicus & g, gal, man, $x$, cel, suc & S, $\mathrm{X}$ & $0.5 \%-5.0 \%$ & ND & $\mathrm{E}, \mathrm{A}, \mathrm{L}, \mathrm{H}$ & $1.90(\mathrm{~g}), 1,64(\mathrm{x})$ & 70 & {$[16,51,52]$} \\
\hline Thermoanaerobacter pseudoethanolicus & g, cel, suc & $\mathrm{S}, \mathrm{X}, \mathrm{P}$ & $4 \%$ & ND & $\mathrm{E}, \mathrm{A}, \mathrm{L}, \mathrm{H}$ & $1.88(\mathrm{~g})$ & $67-69$ & {$[53,54]$} \\
\hline Thermoanaerobacter mathranii & $\mathrm{g}, \mathrm{man}, \mathrm{x}, \mathrm{a}, \mathrm{cel}, \mathrm{suc}$ & $\mathrm{S}, \mathrm{X}, \mathrm{P}, \mathrm{I}$ & $5 \%$ & $2 \% \mathrm{ArC}$ & $\mathrm{E}, \mathrm{A}, \mathrm{L}, \mathrm{H}$ & $1.37(\mathrm{x})$ & 70 & {$[17,55]$} \\
\hline Thermoanaerobacter pentosaceus & $\mathrm{g}$, gal, man, $\mathrm{x}, \mathrm{a}, \mathrm{cel}, \mathrm{suc}$ & $\mathrm{S}, \mathrm{X}, \mathrm{P}, \mathrm{I}$ & $0.5 \%$ & $\begin{array}{c}3.4 \mathrm{~g} / \mathrm{L} \mathrm{FF} \\
3.4 \mathrm{~g} / \mathrm{L} \mathrm{HMF}\end{array}$ & $\mathrm{E}, \mathrm{A}, \mathrm{L}, \mathrm{H}$ & $1.68(\mathrm{x})$ & 70 & {$[56,57]$} \\
\hline Thermoanaerobacter AK5 & g, gal, man, $x$, cel & $\mathrm{S}$ & ND & ND & $\mathrm{E}, \mathrm{A}, \mathrm{H}$ & $1.70(\mathrm{~g}), 1.35(\mathrm{x})$ & 65 & {$[58]$} \\
\hline Thermoanaerobacter $\mathrm{J} 1$ & $\mathrm{~g}, \mathrm{gal}, \mathrm{man}, \mathrm{x}, \mathrm{a}, \mathrm{cel}$ & $\mathrm{S}$ & ND & ND & E, A, H & $1.70(\mathrm{~g}), 1.25(\mathrm{x})$ & 65 & [18] \\
\hline
\end{tabular}

g—glucose; gal—galactose; man—mannose; $\mathrm{x}$ —xylose; a—arabinose; cel—cellobiose; suc—sucrose; X—xylan; ND—not determined; E-ethanol; A—acetate; L—lactate;

$\mathrm{P}$ - pectin; H-hydrogen; *-ability varies depending upon strain; C-cellulose; F-formate; S—starch; FF-furfuraldehyde; HMF-5-hydroxymethyl-furfuraldehyde;

$\mathrm{I}$-inositol; and ArC — aromatic compounds. 
Thermoanaerobacter species have similar physiological characteristics as Thermoanerobacterium species; they are all highly saccharolytic and produce produce end-products including ethanol, acetate, lactate, alanine, $\mathrm{CO}_{2}$, and $\mathrm{H}_{2}$. The genus comprises 19 species and 5 subspecies [29,30]. The main difference between Thermoanaerobacter and Thermoanaerobacterium, apart from phylogenetic distance, is the fact that the majority of Thermoanaerobacter species produce $\mathrm{H}_{2} \mathrm{~S}$ during thiosulfate reduction whereas Thermoanaerobacterium mostly yields elemental sulfur [40]. Another difference lies in the slightly higher $T_{\mathrm{opt}}$ for Thermoanaerobacter species (mostly between $65{ }^{\circ} \mathrm{C}$ and $75{ }^{\circ} \mathrm{C}$ ) as compared with Thermoanaerobacterium (mostly $55-65^{\circ} \mathrm{C}$ ). The type species, Thermoanerobacter ethanolicus and several other species within the genus have been extensively studied for ethanol production [52,59-67] and the highest yields of ethanol production from sugar by a thermophile was observed by this species. Other high yielding species are T. pseudoethanolicus, T. mathranii, Thermoanaerobacter strain AK5 and Thermoanaerobacter strain J1 (Table 1). However, yields vary extensively depending on culture conditions. For example, Thermoanaerobacter strain AK5 produced as high as 1.7 mol ethanol from $1 \mathrm{~mol}$ of glucose in batch cultures but at low $\mathrm{pH}_{2}$, or in the presence of electron scavenging systems (thiosulfate) these yields dropped dramatically and acetate was the main volatile end product instead of ethanol [58]. Recently, Thermoanaerobacter subterraneous was moved to the genus Caldanaerobacter which currently comprises two species: Caldanaerobacter subterraneous (and its four subspecies) and Caldanaerobacter uzonensis [29,30]. Some species of Thermoanaerobacter have also been shown to be able to produce branched-chain alcohols from branched-chain amino acids, for instance isobutanol from valine, and could potentially be used for biofuel production from protein waste in the future [68].

Other representative examples of thermophilic ethanologenic bacteria can be found within the genera of Caldicellulosiruptor, such as Caldicellulosiruptor strain DIB 004C [69], Caloramator species such as C. boliviensis [43], Geobacillus, such as G. thermoglucosidasius [70] and Geobacillus sp. R7 [71], and Paenibacillus strains such as Panibacillus strain 25-07-C [27].

\section{Physiology of Thermophilic Anaerobic Bacteria}

\subsection{Central Metabolism of Sugars to Various end Products}

The theoretical yields of ethanol from $1 \mathrm{~mol}$ of hexose and pentose are $2.0 \mathrm{~mol}$ and 1.66 mol, respectively:

$$
\begin{aligned}
& 1.00 \mathrm{C}_{6} \mathrm{H}_{12} \mathrm{O}_{6} \rightarrow 2.00 \mathrm{C}_{2} \mathrm{H}_{5} \mathrm{OH}+2.00 \mathrm{CO}_{2} \\
& 1.00 \mathrm{C}_{5} \mathrm{H}_{12} \mathrm{O}_{6} \rightarrow 1.66 \mathrm{C}_{2} \mathrm{H}_{5} \mathrm{OH}+1.66 \mathrm{CO}_{2}
\end{aligned}
$$

These ethanol yields are seldom obtained since a part of the substrate is converted to biomass or is directed towards other end products. End product formation patterns depend on both the microorganisms used as well environmental factors in the process (Figure 1).

Most known saccharolytic thermophiles employ the Embden Meyerhof pathway (EMP) [5,72] but do not use pyruvate decarboxylase for converting pyruvate to acetaldehyde (Figure 1) as do yeasts. Instead, pyruvate is reduced to acetyl-CoA via pyruvate ferredoxin oxidoreductase (PFOR) before a second reduction to ethanol via alcohol dehydrogenase (ADH). Thus, a redox imbalance occurs, which is not observed with yeast fermentation, which means that another oxidation step is required, 
most often obtained by production of acetate via acetyl phosphate intermediate by using phosphotransacetylase (PTA) and acetate kinase (AK). Finally, mixed acid fermentation can also include the formation of lactate (Figure 1), formate, and alanine (not shown in Figure 1) from pyruvate via lactate dehydrogenase ( $\mathrm{LDH})$, pyruvate formate lyase and alanine transaminase, respectively. Thus, one of the major obstacles to achieve high ethanol titers in thermophiles is to minimize the variety of end-products formed. However, unlike anaerobic bacteria growing at lower temperatures, mixed acid ferementation occurrs to a lesser extent. Pentoses, including xylose and arabinose, are degraded via the nonoxidative pentose phosphate pathway which lead to intermediates that are directed in the glycolysis pathway [5,10].

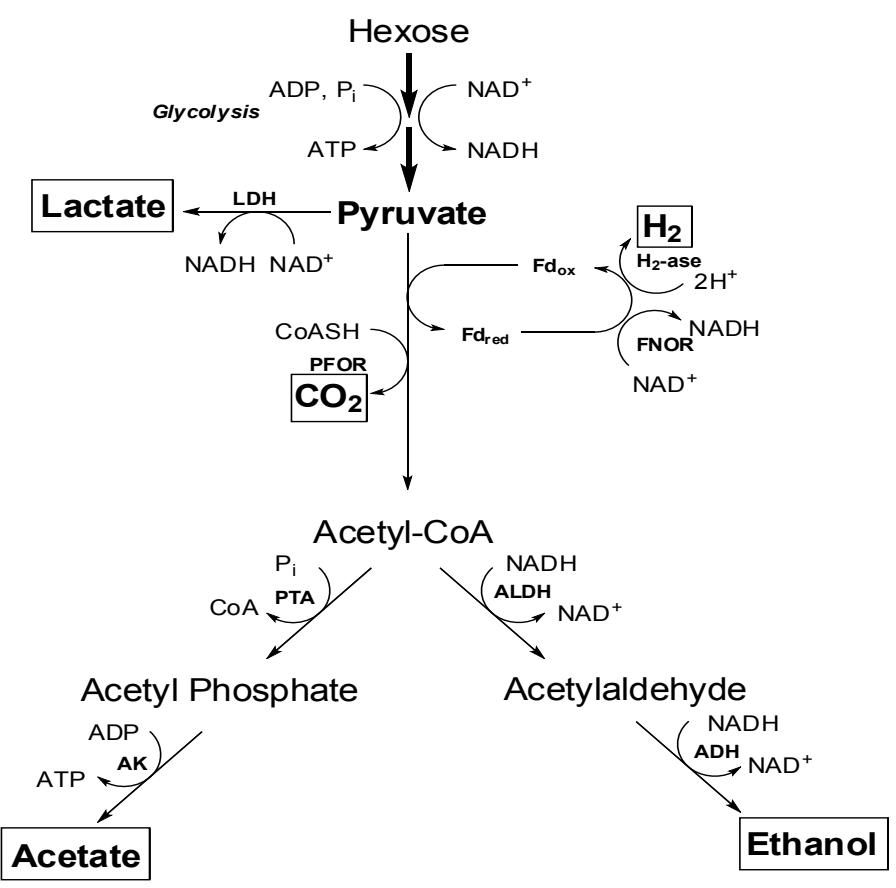

Figure 1. Simplified scheme of glucose degradation to various end products by strictly anaerobic bacteria. Enzyme abbreviations: ALDH - acetaldehyde dehydrogenase; $\mathrm{ADH}$ —alcohol dehydrogenase; AK — acetate kinase; FNOR — ferredoxin oxidoreductase; $\mathrm{H}_{2}$-ase-hydrogenase; LDH-lactate dehydrogenase; PFOR-pyruvate ferredoxin oxidoreductase; and PTA— phosphotransacetylase.

\subsection{Effect of Various Factors for Ethanol Production}

Various factors are known to influence the production of ethanol by thermophilic bacteria: substrate types, the partial pressure of hydrogen, the initial substrate concentration, $\mathrm{pH}$, and temperature. Some of these factors are discussed in detail below.

\subsubsection{Partial Pressure of Hydrogen}

Early observations of the influence of increased hydrogen concentrations on the end product formation of Thermoanaerobacter ethanolicus were reported in 1981 [16]. Higher partial pressure $\left(p \mathrm{H}_{2}\right)$ of hydrogen leads to icreased ethanol production and less acetate production from glucose fermentations $[16,58,73]$. Strict anaerobes produce $\mathrm{H}_{2}$ either via pyruvate ferredoxin oxidorecutase or 
$\mathrm{NAD}(\mathrm{P})$ oxidoreductase [74]. It is a well-known phenonmenon that the increased hydrogen concentrations at lower temperatures affects mesophilic bacteria more severely than thermophiles. The reason is that at lower temperatures, the NADH ferredoxin oxidoreductase (FNOR) that converts $\mathrm{NADH}$ to Fdred is strongly inhibited. The reduction potential is $-450 \mathrm{mV}$ for the $\mathrm{Fd}$ red/Fdox couple but $-320 \mathrm{mV}$ for the $\mathrm{NADH} / \mathrm{NAD}^{+}$couple $[74,75]$. Therefore, at low temperatures, elevated hydrogen concentrations inhibit $\mathrm{H}_{2}$ evolution at much lower concentrations as compared to at high temperatures. Microorganinsms respond to this by directing their reducing equivalents to other more favourable electron acceptors and consequently produce reduced products such as ethanol and lactate (Figure 1). Thus, using bacteria with higher optimum temperatures should lead to a more homogenous end-product formation pattern. From literature, it is difficult to decude if there is "a strict product formation trend" regarding temperature optimum of microbes; it is more likely to be a natural trait of the microbial genomes (i.e., LDH expression).

In their native habitats, the hydrogen generated by fermentative bacteria is rapidly consumed by hydrogen-utilizing organisms, including methanogens and sulfate-reducers [76]. Thus, hydrogen accumulation does not occur allowing for a complete catabolism of glucose to end products. Conversely, batch fermentation with monocultures allows hydrogen to accumulate leading to a change in end production profile in some Thermoanaerobacter species [18,58,77]. This is well known for sugars and some amino acids. For instance, during degradation of glucose, xylose, and the amino acid serine, the major end product for Thermoanaerobacter brockii was ethanol [77]. Under hydrogen scavenging conditions, however, the flow of electrons from glucose degradation was directed away from ethanol but towards acetate with extra ATP produced. Thus, the role of the $p \mathrm{H}_{2}$ in closed fermentation systems is most often critical for end product formation. Several experiments using different liquid-to-gas ratios have revealed that changes in end product formation occur during hydrogen accumulation among species of Clostridium, Thermoanaerobacter, and Caloramator. Hydrogen accumulation in these cultures can have two effects: change the carbon flow to more reduced end products or inhibit substrate degradation. The inhibition observed can be either direct, inhibiting the hydrogenases, or indirect by productions of acids, lowering the $\mathrm{pH}$ in a closed system, and thus stopping further degradation of the substrates.

\subsubsection{Substrate Loadings}

It has been widely reported that thermophilic bacteria are inhibited at relatively low substrate concentrations as compared with yeasts and Z. mobilis [5,42]. The main reason for this is most likely the natural concentration of sugars in the environment from where these microbes originate. Thermophiles are mostly isolated from geothermal areas where the abundance of sugars are usually very low whereas $S$. cerevisae and $Z$. mobilis often originate from fruits containing high concentrations of sugars. By increasing the sugar concentrations in batch cultures of thermophilic bacteria, inhibition of substrate degradation often occurs between $10 \mathrm{mM}$ and $30 \mathrm{mM}[42,58,78]$. Although this inhibiton may also be caused by accumulated hydrogen or by low $\mathrm{pH}$, it could also be an intriquing factor for thermophiles. One strain of Thermoanaerobacter, strain J1, has though been shown to be very tolerant towards high sugar concentrations [18]. This high ethanol producing thermophile produces up to $1.7 \mathrm{~mol}$ ethanol/mol glucose up to initial glucose concentrations of $100 \mathrm{mM}$. 
Recent work on Thermoanaerobacter pentosaceus showed a complete removal of xylose at $13.3 \mathrm{mM}$ initial concentrations but only about 30\% removal at 10 times higher concentrations [78]. Additionally, the ratio of ethanol to acetate and lactate decreased by a factor of more than six resulting in dramatic decrease in ethanol yields.

\subsubsection{Ethanol Tolerance}

One of the most important traits for good ethanol producers is their ethanol tolerance. It is stated that for an economic ethanol recovery to occur, using classical downstream processes, the microorganism should grow and produce ethanol in the presence of at least 4\% (v/v) ethanol [7]. The growth rates of many organisms decrease markedly with increasing ethanol concentrations. The presence of ethanol in fermentation medium causes leaky membranes resulting in loss of energy during cellular metabolism and finally cell lysis. Additionally, ethanol has a strongly denaturing effect on proteins. Again, yeasts and Z. mobilis tolerate much higher ethanol concentrations as compared to thermophiles mainly due to their fatty acid composition structure [13].

Most studies on ethanol tolerance of wild-type species of thermophiles show tolerance between $0.5 \%(\mathrm{v} / \mathrm{v})$ and $3.0 \%(\mathrm{v} / \mathrm{v})[5,56,79,80]$. However, there have been substantial efforts to increase ethanol tolerance of wild type species, earliest experiments include studies with Thermoanaerobacterium thermosaccharolyticum [81,82]. The highest ethanol tolerance observed for a thermophile has been with a mutant strain of Thermoanaerobacter ethanolicus (12.7\% v/v) [83]. However, later studies with one of its mutant derivatives, JW200 Fe 4, showed much less tolerance [51]. Another Thermoanaerobacter strain has also been intensively investigated on the subject, Thermoanaerobacter BG1L1, an efficient xylose degrader. This bacterium showed $8.3 \%(\mathrm{v} / \mathrm{v})$ tolerance in continuous culture studies [61]. Increased ethanol tolerance was also observed with Thermoanaerobacter thermohydrosulfuricus 39E by successively sub-culturing the strain to higher ethanol concentrations [79]. The resulting mutant strain 39EA tolerated $10.1 \%\left(\mathrm{v} / \mathrm{v}\right.$ ethanol) at $45{ }^{\circ} \mathrm{C}$ but only $2.6 \%(\mathrm{v} / \mathrm{v})$ at $68{ }^{\circ} \mathrm{C}$. Additionally, the ethanol yields dropped from $1.5 \mathrm{~mol}$ ethanol $/ \mathrm{mol}$ glucose to $0.6 \mathrm{~mol}$ ethanol $/ \mathrm{mol}$ glucose.

There is still much debate concerning ethanol tolerance of thermophilic anaerobes [82]. Natural tolerance is almost always below $3 \%-4 \%(\mathrm{v} / \mathrm{v})$ and although strains can be naturally manipulated by indirect mutagenesis, their ethanol yields drop substantially. Clearly, a better understanding of the fundamental mechanisms of ethanol tolerance for thermoanaerobes, such as cell membrane alterations and enzymatic regulation, is needed [51,53,84,85].

\subsubsection{Other Culture Parameters}

Other environmental factors of importance for thermophilic bacteria is their $\mathrm{pH}$ and temperature growth optimum, their tolerance towards inhibitory compounds like furfuraldehyde and 5-hydroxymethyl-furfuraldehyde (5-HMF) and their need for trace elements and vitamins often originating from complex medium supplements like yeast extract.

Inhibitory compounds, like furfuraldehyde, 5-HMF, and aromatic compounds derived from lignin such as $p$-coumaryl alcohol, coniferyl alcohol, sinapyl alcohol and related derivatives, are often formed during pretreatment of biomass. These compounds may be problematic during microbial fermentation of the sugars in relatively low concentrations [57,86,87]. Although tolerance towards 
inhibitory compounds has not been wiedely reported in literature, at least one thermophilic bacteria, Thermoanaerobacterium AK17, is known to tolerate a maximum of $4 \mathrm{~g} / \mathrm{L}$ of furfuraldehyde and $6 \mathrm{~g} / \mathrm{L}$ of 5-HMF [42]. The effects of inhbitory compounds may however be circumented by either using highly tolerant microbes or by removing these compounds from the hydrolysates prior to fermentation.

For large scale ethanol production to be economically feasable, it is of great importance that the relevant microbes can grow and produce ethanol without the addition of expensive compounds, like trace elements and vitamins. Most laboratory scale experiments on thermophilic bacteria use defined medium, often containing phosphate buffers, trace elements, vitamin solutions and yeast extract. Unfortunately, the yeast extract seems to be of great importance for metabolic processes in thermophiles although there are some examples of good ethanol yields in media with low yeast extract concentrations [88]. In the future, more emphasis should be placed on isolating good ethanol producers requiring low concentrations of vitamins, trace elements and yeast extract.

\section{Production of Ethanol from Lignocellulose}

While knowledge of the ethanologenic nature of thermophilic anaerobes was established early on, the focus on the fermentation of carbohydrate substrates did not come forth until the early 1980s in response to high oil prices. The earliest studies on bioethanol by fermentation of simple subtrates by thermophilic clostridia focused on Thermoanaerobacterium saccharolyticum, Thermoanaerobacter brockii, and Clostridium thermocellum $[66,67,86]$ but this first generation ethanol production is not within the scope of this review.

The production of bioethanol from lignocellulosic biomass by thermoanaerobes has been widely reported in the literature with the most emphasis placed on Clostridium thermocellum in addition to species within the genera Thermoanaerobacterium and Thermoanaerobacter. There is a large variation in the type and concentration of biomass used, fermentation processes (batch, semi-batch, continuous), pretreatment methods as well as whether pure or mixed cultures are used.

The maximum yield of ethanol obtained from glucose fermentation is $2 \mathrm{~mol}$ ethanol/g glucose $(0.51 \mathrm{~g} / \mathrm{L}$ or $11.1 \mathrm{mM})$. Considering the complex structure of lignocellulosic biomass, it is not surprising that yields are usually considerably lower from such substrates (Table 2). Early experiments on ethanol yields from complex biomass originate from studies on Thermoanaerobacter ethanolicus and Clostridium thermocellum using hemicellulose from birch- and beechwood [89]. Clostridium thermocellum produced $7.2 \mathrm{mM} / \mathrm{g}$ and $8.0 \mathrm{mM} / \mathrm{g}$ avicel and Whatman paper, respectively (Table 2). Similar yields were obtained from paddy straw, sorghum stover and corn stubs, pretreated with alkali [90]. In all studies mentioned above with Clostridium thermocellum, the concentration of cellulose was $8.0 \mathrm{~g} / \mathrm{L}$ or lower. Later studies with this bacterium showed that increased concentrations of both grass and avicel hydrolysates lowered these yields considerably [91]. Thermoanaerobacterium saccharolyticum HG8 produced $6.3 \mathrm{mM}$ of ethanol per gram of xylan from wheat straw hydrolysates [86]. The highest ethanol yields reported from complex biomass are by Thermoanaerobacter BG1L1 grown on corn stover and wheat straw $[60,92]$. The biomass was pretreated with acid or wet oxidation and ethanol yields were up to $9.2 \mathrm{mM} / \mathrm{g}$ for biomass hydrolysates. 
Table 2. Examples of ethanol production from lignocellulosic biomass by thermophilic bacteria. Cultivation were either in batch or continuous (con). Ethanol yields given in $\mathrm{mM} / \mathrm{g}$ substrate degraded as well as substrate concentrations and incubation temperature are also shown. A-acid; Alk—alkaline; E—enzymatic; and WO—wet oxidation.

\begin{tabular}{|c|c|c|c|c|c|c|c|}
\hline Organisms & Substrate & Fermentation mode & Substrate (g/L) & Pre-treatment & Ethanol yields (mM/g) & $T\left({ }^{\circ} \mathrm{C}\right)$ & References \\
\hline Clostridium thermocellum & Avicel & Batch & 2.5 & A & 5.00 & 60 & {$[93]$} \\
\hline Clostridium thermocellum & Avicel & Con & 5.0 & A & 5.48 & 60 & [94] \\
\hline Clostridium thermocellum & Whatman paper & Batch & 8.0 & None & $7.20-8.00$ & 60 & {$[95]$} \\
\hline Clostridium thermocellum & Paddy straw & Batch & 8.0 & None & $6.10-8.00$ & 60 & {$[95]$} \\
\hline Clostridium thermocellum & Sorghum stover & Batch & 8.0 & None & $4.80-8.10$ & 60 & {$[95]$} \\
\hline C. thermocellum and C. thermolacticum & Microcrystal cellulose & Batch & 10.0 & None & 9.1 & 57 & {$[96]$} \\
\hline Clostridium AK1 & Hemp & Batch & 5.0 & $\mathrm{~A} / \mathrm{Alk}$ & 3.5 & 50 & [48] \\
\hline Thermoanaerobacter pentosaceus & Rapeseed straw & Con & 50 & Alk & 1.40 & 70 & [57] \\
\hline Thermoanaerobacter mathranii & Wheat straw & Batch & 6.7 & $\mathrm{WO} / \mathrm{E}$ & 2.61 & 70 & [87] \\
\hline Thermoanaerobacter mathranii & What straw & Batch & 60.0 & $\mathrm{WO} / \mathrm{E}$ & 5.30 & 70 & {$[97]$} \\
\hline Thermoanaerobacter ethanolicus & Beet molasses & Batch & 30.0 & None & 4.81 & 65 & {$[98]$} \\
\hline Thermoanaerobacter BG1L1 & Corn stover & Batch & $25.0-150.0$ & $\mathrm{WO} / \mathrm{E}$ & $8.50-9.20$ & 70 & {$[60]$} \\
\hline Thermoanaerobacter BG1L1 & Wheat straw & Batch & $30.0-120.0$ & $\mathrm{WO} / \mathrm{E}$ & $8.50-9.20$ & 70 & {$[92]$} \\
\hline Thermoanaerobacter BG1L1 & Corn stover & Con & $25.0-150.0$ & $\mathrm{WO} / \mathrm{E}$ & $8.50-9.20$ & 70 & {$[60]$} \\
\hline T. ethanolicus & Wood HL & Batch & 8.0 & $\mathrm{E}$ & $3.30-4.50$ & 70 & {$[89]$} \\
\hline Thermoanaerobacter AK5 & Whatman paper & Batch & 2.25 & $\mathrm{E}$ & 7.7 & 65 & {$[58]$} \\
\hline Thermoanaerobacter AK5 & Grass & Batch & 4.5 & $\mathrm{~A} / \mathrm{E}$ & 4.31 & 65 & {$[58]$} \\
\hline Thermoanaerobacter $\mathrm{J} 1$ & Whatman paper & Batch & 4.5 & $\mathrm{E}$ & 7.5 & 65 & {$[18]$} \\
\hline Thermoanaerobacter J1 & Hemp & Batch & 4.5 & $\mathrm{~A} / \mathrm{E}$ & 4.3 & 65 & {$[18]$} \\
\hline T. saccharoylticum & Xylan & Batch & 10.0 & WO & 6.30 & 60 & {$[86]$} \\
\hline Thermoanaerobacterium AK17 & Cellulose & Batch & 2.5 & $\mathrm{E}$ & 8.6 & 60 & {$[42]$} \\
\hline Thermoanaerobacterium AK17 & Grass & Batch & 2.5 & $\mathrm{~A} / \mathrm{Alk} / \mathrm{E}$ & 5.5 & 60 & [42] \\
\hline
\end{tabular}


Studies on ethanol production by Thermoanaerobacterium strain AK17, isolated from an Icelandic hot spring, grown on various types of lignocellulosic biomass were reported by Sveinsdottir and co-workers [27]. Batch culture studies using $7.5 \mathrm{~g} / \mathrm{L}$ of cellulose, grass and newspaper, pretreated with heat and enzymes, showed ethanol yields of 2.0 (paper) $\mathrm{mM} / \mathrm{g}, 2.9$ (grass) $\mathrm{mM} / \mathrm{g}$ and 5.8 (cellulose) $\mathrm{mM} / \mathrm{g}$ biomass. Optimization experiments were recently done on this strain where ethanol yields on grass and cellulose were increased to $4.0 \mathrm{mM} \cdot \mathrm{g}^{-1}$ and $8.6 \mathrm{mM} \cdot \mathrm{g}^{-1}$, respectively. The main environmental factors increasing ethanol yields were the use of acid/alkali for pretreatment and the lowering of the substrate concentration from $7.5 \mathrm{~g} / \mathrm{L}$ to $2.5 \mathrm{~g} / \mathrm{L}$ [42]. Recent investigations on two Thermoanaerobacter strains, AK5 and J1 showed promising results from various types of hydrolysates made from chemically and enzymatically pretreated lignocellulosic biomass (Table 2) $[18,58]$. Recent investigaton on a co-culture of $C$. thermocellum and $C$. thermolactimum showed $75 \%$ and $90 \%$ ethanol yields on crystaline cellulose and xylose, respectively [96]. Thermoanaerobacter pentosaceus has been investigated for its ethanol production capacity on rapeseed straw in coculture with S. cerevisae [57]. This is the first report on a two-stage process for second generation bioethanol production where thermophilic bacterium is used together with a yeast.

\section{Evolutionary Adaptation and Genetic Engineering of Thermophiles}

To date, no single organism has met all the requirements for highly efficient ethanol production from lignocellulosic biomass. There are two general strategies of enhancing ethanol production by wild type microorgansims: evolutionary adaptation of natural strains or genetic modification. Originally, classical methods such as the selection of clones and nonspecific mutagenesis were used to improve ethanol production in thermophiles [99]. While these methods are time-consuming, genetic modification is not without drawbacks as modified strains can exhibit poor growth and unexpected shifts in end product formation.

\subsection{Evolutionary Adaptation}

The use of classical evolutionary adaptation methods, such as non-specific mutagenesis and artificial selection, to enhance specific traits of microorganisms for industrial bioethanol production has been applied to thermophilic anaerobes on a limited basis. As previously mentioned, one of the major drawbacks of working with thermophilic anaerobes is their low substrate and ethanol tolerance compared to their mesophilic counterparts.

Three new strains of Thermoanaerobacter ethanolicus were obtained by selection of pyruvate and iron deprivation [100] leading to enhanced ethanol tolerance $(10 \% \mathrm{v} / \mathrm{v})$ at substrate concentrations above $10 \mathrm{~g} / \mathrm{L}$. Recent investigation on Clostridium thermocellum showed increased ethanol tolerance (up to $5 \% \mathrm{v} / \mathrm{v}$ ) by stepwise increasing and transferring cultures to increased ethanol concentrations [101]. While adapting non-thermophilic strains to higher substrate concentrations as well as inhibitory substances have been reported, there are few examples of these techniques being applied to thermoanaerobes. Thermoanaerobacter pentosaceus has thought been gradually adapted to higher substrate concentrations and demonstrated higher ethanol tolerance and substrate utilization [102]. Thus, evolutionary adaptation, may still be used for evolving of wild type strains with enhanced tolerance to high ethanol titers, high substrate concentrations and increased concentrations of 5-HMF and fufuraldehyde. 


\subsection{Genetic Engineering}

Recent advances in genome sequencing technology and gene transfer systems have resulted in a new generation of engineered thermophilic ethanologens [103,104]. The main drawback of most wild type thermophiles is their production of mixed end products resulting in lower ethanol yields and the fact that highly ethanolgenic organisms are not natively celluloytic and vise versa. Efforts to metabolically engineer thermophilic organisms for consolidated bioprocessing (CBP) have focused on two strategies: increasing the ethanol yields of cellulase-producing organisms or expressing cellulases in highly ethanologenic organisms [103]. The first approach involves increasing ethanol yields by eliminating other fermentation products and improving ethanol tolerance whereas the second approach involves addition of cellulolytic genes to the genome of a good ethanol producing bacterium.

Thermoanaerobacterium saccharolyticum was the first thermophile to be genetically modified to enhance its ethanol production in 2004 [105]. In the past 10 years, several other ethanologenic thermophiles have been genetically modified in an effort to increase ethanol titers and minimize the formation of other end products such as acetate and lactate (Table 3 ).

Deletion of genes that lead to production of other end-products, and thus, hopefully, increase ethanol production capacity is the most obvious way to increase ethanol titers. This has indeed been done by knocking out LDH in Thermoanaerobacterium saccharolyticum [49,103], Thermoanaerobacter mathranii [55], Clostridium thermocellum [106] and Geobacillus thermoglucosidasius [70].

Clostridium thermocellum is a cellulolytic bacterium producing a mixture of ethanol, acetate, lactate, hydrogen and carbon dioxide [96]. Its capability of hydrolysing cellulose and producing ethanol has led to intensive investigations in this area. The first successful transformation of the species was performed in 2006 [107], later on leading to the development of genetic systems to knock out the PTA gene and thus acetate formation [106]. This strain however grew abnormally but retained its cellulase activity. Later work on $C$. thermocellum showed improved ethanol yields in a $\Delta \mathrm{hpt}, \Delta \mathrm{ldh}, \Delta \mathrm{pta}$ evolved strain as well as successful use of co-culture of this strain with Thermoanaerobacterium saccharolyticum [106].

From the early work on Thermoanaerobacterium saccharolyticum using electroporation and shuttle vectors [108], this strain has been further modified by inserting a cellobiohydrolase gene from Clostridium thermocellum into its genome [109]. Later work with Thermoanaerobacterium saccharolyticum involves a LDH gene knock out [105] and a double knock out of both LDH and AK [49]. Clearly, by knocking out acetate formation led to less available energy, thus less cell biomass and increased ethanol yields, both from glucose and xylose. Another double knock out of Thermoanaerobacterium saccharolyticum focuses on the electron transfer system of the bacterium [110]. The authors deleted the hfs gene cluster and ldh gene which encode for hydrogenase and LDH, respectively. Again, a considerable increase in ethanol (44\%) production was obtained as compared with the wild type. 
Table 3. Ethanol yields of genetically engineered thermophilic bacteria from different substrates and fermentation conditions: ack-acetate kinase; GldA-glycerol dehydrogenase A; hfs-hydrogenase; hpt—hypoxanthine phosphoribosyl transferase; pdh—pyruvate decarboxylase; pyrF—orotidine-5-phoshate decarboxylase; pfl—pyruvate formate lyase; and ure —urease.

\begin{tabular}{|c|c|c|c|c|c|c|}
\hline Strain & Genotype & Substrate & Concentration (g/L) & Mode & Ethanol yields (mol/mol) & References \\
\hline C. thermocellum & $\Delta$ pyrF, $\Delta$ pta::gapDHp-cat & Cellobiose & 5.0 & Batch & 0.59 & [111] \\
\hline C. thermocellum & $\Delta$ pyrF, $\Delta$ pta::gapDHp-cat & Avicel & 5.0 & Batch & 0.71 & [111] \\
\hline C. thermocellum adhE*(EA) $\Delta \mathrm{ldh}$ & $\Delta \mathrm{hpt}, \Delta \mathrm{ldh}$ & Cellobiose & 5.0 & Batch & 0.37 & [112] \\
\hline C. thermocellum & $\Delta \mathrm{hpt}, \Delta \mathrm{ldh}, \Delta \mathrm{pta}$ (evolved) & Avicel & 19.5 & Batch & 1.08 & [112] \\
\hline C. thermocellum/T. saccharolyticum & $\Delta \mathrm{hpt}, \Delta \mathrm{ldh}, \Delta \mathrm{pta}$ (evolved) and $\Delta \mathrm{pta}, \Delta \mathrm{ack}, \Delta \mathrm{ldh}$ & Avicel & 19.5 & Batch & 1.26 & [112] \\
\hline T. saccharolyticum TD1 & $\Delta \mathrm{ldh}$ & Xylolse & 5.0 & Batch & 0.98 & [112] \\
\hline T. saccharolyticum ALK2 & $\Delta \mathrm{pta}, \Delta \mathrm{ack}, \Delta \mathrm{ldh}$ & Cellobiose & 70.0 & Con & ND & {$[49]$} \\
\hline T. saccharolyticium HK07 & $\Delta \mathrm{ldh}, \Delta \mathrm{hfs}$ & Cellobiose & 1.8 & Batch & 0.86 & {$[110]$} \\
\hline T. saccharolyticium M0355 & $\Delta \mathrm{ldh}, \Delta$ ack $\Delta$ pta & Cellobiose & 50.0 & Batch & 1.73 & [106] \\
\hline T. saccharolyticum M1051 & $\Delta \mathrm{ldh}, \Delta$ ack $\Delta$ pta, ureABCDEFG & Cellobiose & 27.5 & Batch & 1.73 & [110] \\
\hline G. thermoglucosidasius TM242 & $\Delta \mathrm{ldh}-$, pdh up, pflB- & Glucose & 34.0 & Batch & 1.73 & {$[70]$} \\
\hline G. thermoglucosidasius TM242 & $\Delta \mathrm{ldh}-$, pdh up, $\Delta$ pflB- & Glucose & 34.0 & Batch & 1.84 & {$[70]$} \\
\hline G. thermoglucosidasius TM242 & $\Delta \mathrm{ldh}-, \Delta \mathrm{pdh}$ up, $\Delta \mathrm{pflB}-$ & Xylose & 29.0 & Batch & 1.37 & {$[70]$} \\
\hline T. mathranii BG1L1 & $\Delta \mathrm{ldh}$ & Wheat straw & $30-120$ & Con & $1.53-1.67$ & {$[92]$} \\
\hline T. mathranii BG1G1 & $\Delta \mathrm{ldh}$, GldA & Glucose + glycerol & 5.0 & Batch & 1.68 & {$[55]$} \\
\hline T. mathranii BG1G1 & $\Delta \mathrm{ldh}$, GldA & Xylose + glycerol & 5.0 & Batch & 1.57 & {$[55]$} \\
\hline T. mathranii BG1G1 & $\Delta \mathrm{ldh}$, GldA & Xylose + glycerol & 12.8 and 7.2 & Con & 1.53 & {$[55]$} \\
\hline
\end{tabular}


Thermoanaerobacter mathranii was isolated from an Icelandic hot spring [17] and has later been modified and used in several investigations. The first mutant generated was BG1L1 by knocking LDH out. This strain showed more than two-fold increase in ethanol production as compared with the wild type, up to $1.52 \mathrm{~mol}$ ethanol/mol xylose [113]. The strains have also been shown to have similar ethanol yields from undetoxified pretreated corn stover and wheat straw [60,92]. Further manipulation of this strain involves overexpression of $\mathrm{NAD}(\mathrm{P}) \mathrm{H}$-dependent bi-functional aldehyde/ADH, resulting in the strain BG1E1. Clearly, this enzyme is of great importance for ethanol production and its overexpression resulted in higher ethanol yields [55]. The electron balance for sugar degradation was also examined using mannitol, which is more reduced than glucose and xylose, as a substrate [114] leading to more ethanol production. One more mutant of Thermoanaerobacter mathranii was finally developed, BG1G1 where the gene encoding for $\mathrm{NAD}^{+}$-dependent glycerol dehydrogenase was inserted. This increased ethanol production by $40 \%$ as compared with the wild type. Additionally, the strain utilized the highly reduced glycerol and co-metabolism of glycerol and sugars.

Thermophilic bacteria within the genus of Geobacillus have also attracted increased interest due to their ethanol production capacity recently. These bacteria are facultative anaerobes and can ferment various sugars to pyruvate by pyruvate dehydrogenase to acetyl-Coenzyme A [70]. Under aerobic conditions, however, pyruvate formate lyase is used and a variety of end products are formed. A research group led by Cripps [70] manipulated Geobacillus thermoglucosidasius, obtaining an upregulated expression of pyruvate dehydrogenase under anaerobic conditions in lactate dehydrogense-inactivated strain. Several mutants were developed (TM89; ldh knockout; TM180; ldh knocout and upregulated pdh; TM242; ldh, pdh up, and pfl). The TM180 strain produced $1.45 \mathrm{~mol}$ ethanol/mol hexose (the wild type produced $0.39 \mathrm{~mol}$ ethanol/mol hexose and TM89 $0.94 \mathrm{~mol}$ ethanol $/ \mathrm{mol}$ hexose). The triple mutant TM242 produced $1.65 \mathrm{~mol}$ ethanol/mol hexose. This mutant also showed good yields on xylose $(1.33 \mathrm{~mol} / \mathrm{mol})$ and good productivity rates. Geobacillus thermoglucosidasius has recently be genetically modified by expressing pyruvate decarboxylase from Gluconobacter oxydans [115]. Ethanol yields obtained were as high as $1.37 \mathrm{~mol}$ ethanol $/ \mathrm{mol}$ glucose.

Overall, efforts to engineer thermophilic anaerobes to increase ethanol titers has resulted in modest gains in yields while minimizing or eliminating the formation of unwanted end products. Future targets for genetic manipulation might include the inclusion of the cellulolytic machinery of $C$. thermocellum into highly ethanolgenic Thermoanaerobacter and Thermoanaerobacterium strains.

\section{Process Technology for Thermophilic Bioethanol Production}

The main barrier using lignocellulosic biomass as a feedstock for bioethanol production lies in the cost of pretreatment and enzymatic hydrolysis. In order to improve the economic feasibility of the second generation bioethanol production, the number of process steps needs to be reduced. Thus, there has been increased emphasis on integrated process technologies that reduce the number of process steps resulting in decreased processing time, reduced pretreatment costs, and increased energy efficiency of bioethanol production.

While the types of a bioethanol processes may vary due to feedstock, pretreatment, and organism selection, the process of converting complex lignocellulosic substrates into ethanol is performed in four steps: 
1) Physical and chemical pretreatment of biomass;

2A) Hydrolases production (cellulases, hemicellulases, etc.);

2B) Saccharification (enzymatic hydrolysis of polymers to hexoses and pentoses);

3) Fermentation (of both pentoses and hexoses);

4) Product recovery.

There are several review articles on ethanol production from lignocellulosic biomass [5,10,99]. Below is a short description of each step.

\subsection{Process Steps for the Conversion of Lignocellulosic Biomass to Ethanol}

\subsubsection{Pretreatment of Biomass}

Prior to fermentation, lignocellulosic biomass requires pretreatment to separate its components making them more accessible for enzyme hydrolysis and thus converting the polymeric carbohydrates into sugars. The main aim of pretreatment is to minimize energy consumption while maximizing the sugars liberated and this still remains a major challenge as no single pretreatment method is universally applicable $[4,116,117]$. There are various chemical, physical, physio-chemical, and biological pretreatment methods available. A common pretreatment strategy involves the application of high temperature and pressure in a mildly acidic solution to liberate lignocellulose from the matrix. A clear advantage to using thermophilic organisms is that the pretreated biomass would not require as much cooling prior to subsequent process steps (saccharification and fermentation). A potential drawback, however, is the generation of 5-HMF and furfuraldehyde from the liberated glucose and xylose, respectively, in addition to the formation of inhibitory compounds derived from lignin. For more comprehensive description of pretreatment methods, recent review articles should be examined [118-120]. The main outcome of pretreatment is the removal of lignin and separation of cellulose and hemicellulose.

\subsubsection{Enzymatic Hydrolysis and Saccharification}

The most expensive step in the production of bioethanol from lignocellulosic biomass is the production and/or use of commercial enzymes for conversion of the hemicelluloses and celluloses to sugars [121]. An ideal enzyme system for bio-refinery applications should be generated in situ and useable in continuous culture, have high activity, be stable under process conditions including elevated temperatures, be resistant to inhibitory compounds such as aldehydes, and possess a long half-life. At present, no commercially available enzyme is suitable for high-temperature applications $\left(>55^{\circ} \mathrm{C}\right)$; most available enzymes have been isolated from mesophilic organism with operating temperatures below $50{ }^{\circ} \mathrm{C}$ and have poor yields and relatively slow rates of hydrolysis [122].

Podkaminer and co-workers [123] discovered a previously unknown shortcoming of the use of thermo-tolerant aerobic fungal enzymes: they are not well suited for anaerobic conditions, thus highlighting the need for highly active anaerobic and ethanol tolerant enzyme systems. A recent review on the use of thermophilic enzymes for lignocellulosic biomass hydrolysis was recently published [122].

Another possibility for the degradation of cellulose and hemicellulose would be the use of cellulolytic microorganisms in situ (biological treatment). Well-known degraders are fungi and bacteria that can change the structure of lignocellulosic biomass so that it becomes more accessible 
to enzymes. Cellulases are required for the degradation of cellulose and they are produced by fungi such as T. reesei, Aspergillus niger, and the bacterium C. thermocellum, as previously mentioned [120]. The fact that biological pretreatment is a chemical-free method, and therefore an inherently environmentally friendly method makes it a particularly desirable pretreatment option. The energy input is also very low but the obvious drawback is that it is a very time consuming process and it requires a large volume and active control of growth conditions [121].

\subsubsection{Fermentation}

The broad substrate range of many thermophilic ethanol producers makes them an excellent choice for bioethanol production when lignocellulose is used as the substrate. Coupled with higher operating temperatures, which drives end-product formation and limits the risk of mesophilic contamination, both hexoses and pentoses are degraded to ethanol. Another advantage to using thermophilic ethanologens is that many are capable of simultaneous hexose and pentose fermentation [26]. Traditional mesophilic platform organisms, including $S$. cerevisae and E. coli, typically degraded glucose before metabolizing other compounds; this phenomenon is frequently referred to as "the glucose effect".

Given that the biochemical conversion of sugars to ethanol is an exothermic process, mesophilic organism require active cooling. This problem is somewhat mitigated with thermophilic organisms and can be coupled to in situ ethanol removal thus decreasing the amount of external energy needed for process cooling and product recovery while driving end production formation and limiting ethanol inhibition. This becomes particularly relevant in the context of consolidated bioprocesses.

\subsubsection{Product Recovery}

Ethanol is typically separated from fermentation mixtures by distillation and operating at elevated process temperatures theoretically also allows for in situ ethanol removal (so-called "self-distillation"). At atmospheric pressure, ethanol boils at $78.4{ }^{\circ} \mathrm{C}$ which is only a few degrees above the $T_{\text {opt }}$ of many ethanologenic thermophilic bacteria. Ethanol, being volatile, could be continuously removed at sub-boiling temperatures to further drive processes to completion.

\subsection{Integrated Processes for Ethanol Production from Lignocellulose}

There are mainly four ways to convert complex biomass to ethanol products after pretreatment: (1) separate hydrolysis and fermentation (SHF); (2) simultaneous saccharification and fermentation (SSF); (3) simultaneous saccharification and co-fermentation (SSCF); and (4) CBP. The three ways most relevant processes for thermophilic ethanol production are SHF, SSCF and CBP since there is no need for a separate hexose and pentose fermentation as used in the SSF process. The main outline of the differences in these processes is shown in Figure 2. The SHF process is when the polymer hydrolysis and fermentation are performed in separate steps, whereas the SSF and SSCF uses a single step and the difference between the two is that the latter includes both pentose and hexose fermentation but the former only hexose fermentation. CBP applies when enzymatic production, cellulose degradation and fermentation occurs in single step. 


\section{Bioethanol Process Steps}

\begin{tabular}{cccccc} 
Step 1) & Step 2A) & Step 2B) & Step 3A) & Step 3B) & Step 4) \\
Pretreatment & Enzyme Production & Saccharification & C6 fermentation & C5 fermentation & Distillation \\
\hline
\end{tabular}

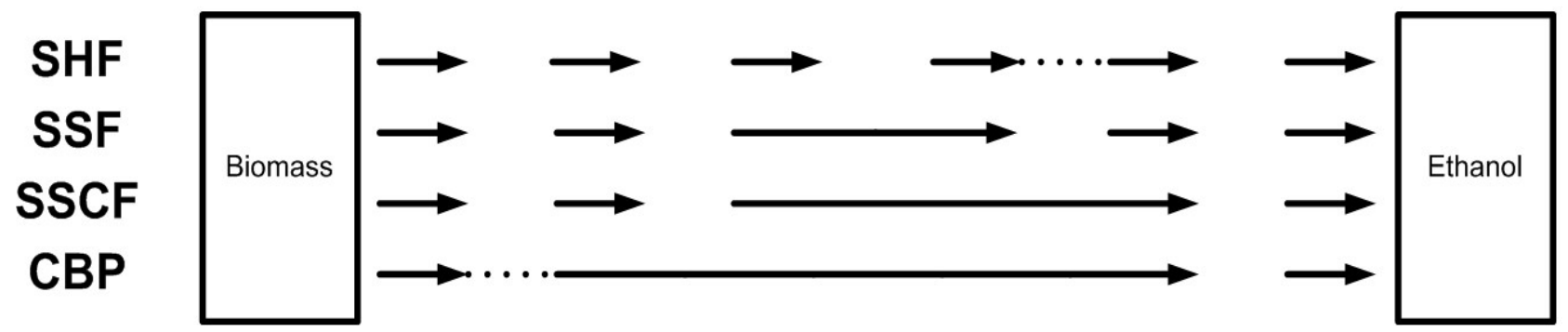

Figure 2. Process steps of bioethanol production processes. SHF-separate hydrolysis and fermentation; SSF_-simultaneous saccharification and fermenation; SSCF-simultaneous saccharification and co-fermentation; $\mathrm{CBP}$ - consolidated bioprocessing; $\mathrm{C} 6$ - hexose; and $\mathrm{C} 5$ - pentose.

\subsubsection{Separate Hydrolysis and Fermentation}

The most traditional method for ethanol production is the two-stage SHF process in which the hydrolysis of biopolymers to sugars and sugar fermentation are conducted separately. The main advantage of SHF is that both hydrolysis and fermentation are performed at their optimum conditions. The main limitation however is the accumulation of glucose during enzymatic hydrolysis that can strongly inhibit further cellulase activity [10].

\subsubsection{Simultaneous Saccharification and Fermentation and Simultaneous Saccharification} and Co-Fermentation

To avoid the inhibitory effect of sugars on cellulases and to reduce the number of discrete process steps, two other models (SSF and SSCF) have been adapted where both saccharification and fermentation occurs in the same fermentation vessel. The key advantages of SSF include increased hydrolysis rates thus requiring lower enzyme loadings, decreased need for sterile conditions, decreased reaction times, and lower reactor volume [124,125]. The simultaneous consumption of liberated sugars decreases the product inhibition experienced by the hydrolases while the rapid consumption of monosugars minimizes the risk of contamination by other saccharolytic organisms and keeps substrate levels low thus avoiding inhibition of both the fermentative organisms and the hydrolytic enzymes [126]. The challenge of these processes is the compatibility of the optimal conditions for the hydrolysis and the microorganisms used for fermentation. Enzymatic hydrolysis is usually performed at $50{ }^{\circ} \mathrm{C}$, while most common fermentative microorganisms used have optimal growth temperature between $28{ }^{\circ} \mathrm{C}$ and $37^{\circ} \mathrm{C}$. This results in lower efficiency and lower ethanol yields $[119,126]$.

A number of challenges, however, need to be overcome to adequately address the production of bioethanol from lignocellulosic biomass. As the enzymatic conversion of polymers to monosugars is typically performed at $50{ }^{\circ} \mathrm{C}$ and $\mathrm{pH}=4.5$ [127], the use of fermentative mesophiles either means operating at a "trade off" temperature compromising either the efficiency of the enzyme or growing at a non-optimum temperature. While the thermotolerant yeast Kluyveromyces marxianus has broad 
substrate spectra, the wild type cannot utilize cellobiose limiting its usefulness as the ethanologenic organism in SSF applications. Moderate thermophiles may be a very good option under these conditions as they fall within the operating temperature range of currently available enzymes. A recent SSF study using Thermoanaerobacterium saccharolyticum ALK2 grown on avicel at a concentration of $20 \mathrm{~g} / \mathrm{L}$ found that the enzyme systems used were dramatically inhibited by anaerobic conditions and high ethanol titers [123].

\subsubsection{Consolidated Bioprocessing}

The final process involves the consolidation of all steps of bioethanol production into a single reaction vessel by either a single organism or a co-culture as first proposed by Lynd [128]. Notably, the production of enzymes used in saccharification of biomass is produced in situ in the fermentation vessel leading to lower cost and high efficiencies at the same time [99]. Since this process takes place in a single step, the choice of microorganism used is of great importance. The microorganism chosen must have enzymatic machinery to produce both a variety of hemicellulases and cellulases as well as produce high ethanol titers [129]. So far, there is no wild type microorganism that has all these desired properties. Therefore, there have been several attempts to genetically modify microorganisms for use in CBP processes. There are two main strategies used for this purpose, CBP I and CBP II [130]. The former involves a microorganisms that has the native ability to degrade lignocellulose and is then further engineered to become a powerful ethanol producer. The CBP category II, however, is aimed to genetically engineer microorganisms that is a good ethanol producer but does not have the ability to produce the enzymes needed for the biomass breakdown [130,131].

The best candidates for category CBP I are fungi, free-enzyme bacteria and cellulosome-forming bacteria [131,132]. The thermophile, Clostridium thermocellum could be a good choice for category CBP I organisms due to its multienzyme complex cellulosome. However, its production of by-products like acetate and lactate and its inability to utilize xylose is a major drawback. However, Argyros and co-workers [110] were able to delete the genes encoding LDH and PTA in Clostridium thermocellum and thus increase its ethanol production. A co-culture of this mutant with an organic-acid deficient strain of Thermoanaerobacterium saccharolyticum on avicel $(92 \mathrm{~g} / \mathrm{L})$ resulted in $38 \mathrm{~g} / \mathrm{L}$ of ethanol $(0.41 \mathrm{~g} / \mathrm{g}$ avicel). Many fungi produce a variety of extracellular cellulases in significant amounts and have thus also been looked at as CBP I candidates. Filamentous fungi such as Trichoderma, Aspergillus, Rhizobius, and Fusarium have the ability to directly ferment cellulose to ethanol using two different metabolic routes. The first route involves the aerobic production of cellulases followed by an anaerobic fermentation where ethanol and other by-products such as acetate are produced $[131,133]$.

One of the key advantages for the use of thermophilic bacteria for CBP (or tCBP) is that in situ distillation is an option at higher operating temperatures. Despite this inherent advantage, relatively little work has been published on the use of thermophiles in CBP processes. The main candidates for tCBP are Clostridium thermocellum and Clostridium stercorarium [134] due to their cellulolytic capabilities but complex end product profiles and low ethanol yields have hindered these bacteria to be used in industrial processes. Additionally, bacteria in general produce much lower amounts of cellulases as compared with fungi [135]. However, using a co-culture of cellulolytic thermophiles together with high-ethanol titer bacteria has emerged as a promising path to be taken seriously. 


\section{Conclusions}

For optimal bioethanol production from lignocellulosic biomass the microorganisms used need to be robust in several ways. Among the advantages thermophiles possess is that they have broad substrate spectra and can degrade both hexoses and pentoses simultaneously; some thermophiles natively degrade complex carbohydrates; they operate at temperatures that minimizes contamination risk of mesophiles. Additionally, recent advances have improved ethanol yields by using genetic engineering, often by knocking out metabolic pathways to other end products, have minimized the perceived advantage of mesophiles over thermophiles considerable, although no large scale bioethanol plants with genetically modified microbes is currently operating. On the other hand, yields and tolerance towards inhibitory compounds are less as compared with mesophiles as well as the fact thermophiles are more sensitive towards various environmental variations, especially substrate concentrations, ethanol tolerance, and the partial pressure of hydrogen, although the latter may be used as a tool to increase ethanol yields with thermophiles. From the process point of view, the lack of compatible enzyme systems for consolidated processes such as SSF and CBP is still lingering. Most commercially available enzymes have temperature optima between room temperature and $50{ }^{\circ} \mathrm{C}$ and commercially available cellulases are inhibited by anaerobic conditions and by ethanol [124]. This further highlights the need for enzyme systems that are compatible with an oxygen-free environment so that thermophilic consolidated bioprocesses become a feasible alternative.

Additionally, using stable co-cultures, where one microorganism hydrolyses the sugar polymers and another ferments the released sugars, is an attractive way to go forward but needs further investigations in order to materialize in full scale bioethanol production.

Beyond terrestrial biomass, other feedstocks need to be considered for bioethanol production. Algal biomass is a largely untapped potential substrate for bioethanol production. Unlike terrestrial biomass, marine macro algae lack lignin but contain a much more diverse assortment of carbohydrates, many of which are recalcitrant. Here, the broad substrate utilization spectra of many thermophilic anaerobes could be of great potential.

\section{Acknowledgments}

The authors would like to gratefully thank Eva Maria Ingvadottir for her helpful feedback during the preparation of this manuscript.

\section{Conflicts of Interest}

The authors declare no conflict of interest.

\section{References}

1. European Commission. Directive 2003/30/EC of the European Parliament and of the Council of 8 May 2003 on the promotion of the use of biofuels or other renewable fuels for transport. Off. $J$. Eur. Union 2003, L123, 42-46. 
2. European Commission. Directive 2009/28/EC of the European Parliament and of the Council of 23 April 2009 on the promotion of the use of energy from renewable sources and amending and subsequently repealing Directives 2001/77/EC and 2003/30/EC. Off. J. Eur. Union 2009, L140, 16-47.

3. RFA: Renewable Fuels Association. World Fuel Ethanol Production. 2013. Available online: http://ethanolrfa.org/pages/World-Fuel-Ethanol-Production (accessed on 30 September 2014).

4. Sánchez, Ó.J.; Cardona, C.A. Trends in biotechnological production of fuel ethanol from different feedstocks. Bioresour. Technol. 2008, 99, 5270-5295.

5. Taylor, M.P.; Eley, K.L.; Martin, S.; Tuffin, M.I.; Burton, S.G.; Cowan, D.A. Thermophilic ethanologenesis: Future prospects for second-generation bioethanol production. Trends Biotechnol. 2009, 27, 398-405.

6. Demain, A.L.; Newcomb, M.; Wu, J.H.D. Cellulase, clostridia, and ethanol. Microbiol. Mol. Biol. Rev. 2005, 69, 124-154.

7. Hanh-Hagerdal, B.; Galbe, M.; Gorwa-Grauslund, M.F.; Liden, G.; Zacchi, G. Bio-ethanol the fuel of tomorrow from residues today. Trends Biotechnol. 2006, 24, 549-556.

8. Farrell, A.F.; Plevin, R.J.; Turner, B.T.; Jones, A.D.; O’Hare, M.; Kammen, D.M. Ethanol can contribute to energy and environmental goals. Science 2006, 311, 506-508.

9. Gnansounou, E.; Dauriat, A. Techno-economic analysis of lignocellulosic ethanol: A review. Bioresour. Biotechnol. 2010, 101, 4980-4991.

10. Chang, T.; Yao, S. Thermophilic, lignocellulolytic bacteria for ethanol production: Current state and persepectives. Appl. Microbiol. Biotechnol. 2011, 92, 13-27.

11. Ostergaard, S.; Olsson, L.; Nielsen, J. Metabolic engineering of Saccharomyces cerevisae. Microbiol. Mol. Biol. Rev. 2000, 64, 34-50.

12. Jeffries, T.W. Engineering yeasts for xylose metabolism. Curr. Opin. Biotechnol. 2006, 17, 320-326.

13. He, M.X.; Wu, B.; Qin, H.; Ruan, Z.Y.; Tan, F.R.; Wang, J.L.; Shui, Z.X.; Dai, L.C.; Zhu, Q.L.; Pan, K.; et al. Zymomonas mobilis: A novel platform for future biorefineries. Biotechnol. Biofuels 2014, 7, doi:10.1186/1754-6834-7-101.

14. Turner, P.; Mamo, G.; Karlsson, E.N. Potential and utilization of thermophiles and thermostable enzymes in biorefining. Microb. Cell Fact. 2007, 6, doi:10.1186/1475-2859-6-9.

15. Wagner, I.D.; Wiegel, J. Diversity of thermophilic anaerobes. Ann. N. Y. Acad. Sci. 2008, $1125,1-43$.

16. Wiegel, J.; Ljungdahl, L.G. Thermoanaerobacter ethanolicus gen. nov., spec. nov., a new, extreme thermophilic, anaerobic bacterium. Arch. Microbiol. 1981, 128, 343-348.

17. Larsen, L.; Nielsen, P.; Ahring, B.K. Thermoanaerobacter mathranii sp. nov, an ethanol-producing, extremely thermophilic anaerobic bacterium from a hot spring in Iceland. Arch. Microbiol. 1997, $168,114-119$.

18. Jessen, J.E.; Orlygsson, J. Production of ethanol from sugars and lignocellulosic biomass by Thermoanaerobacter J1 isolated from a hot spring in Iceland. J. Biomed. Biotechnol. 2012, 2012, doi:10.1155/2012/186982.

19. Slobodkin, A.I.; Tourova, T.P.; Kuznetsov, B.B.; Kostrikina, N.A.; Chernyh, N.A.; Bonch-Osmolovskaya, E.A. Thermoanaerobacter siderophilus sp. nov., a novel dissimilatory Fe(III)-reducing, anaerobic, thermophilic bacterium. Int. J. Syst. Bacteriol. 1999, 49, 1471-1478. 
20. Mendez, B.S.; Pettinari, M.J.; Ivanier, S.E.; Ramos, C.A.; Sineriz, F. Clostridium thermopapyrolyticum sp. nov., a cellulolytic thermophile. Int. J. Syst. Bacteriol. 1991, 41, 281-283.

21. Fong, J.C.N.; Svenson, C.J.; Nakasugi, K.; Leong, C.T.C.; Bowman, J.P.; Chen, B.; Glenn, D.R.; Neilan, B.A.; Rogers, P.L. Isolation and characterization of two novel ethanol-tolerant facultative-anaerobic thermophilic bacteria strains from waste compost. Extremophiles 2006, 10, $363-372$.

22. Sekiguchi, Y.; Imachi, H.; Susilorukmi, A.; Muramatsu, M.; Ohashi, A.; Harada, H.; Hanada, S.; Kamagata, Y. Tepidanaerobacter syntrophicus gen. nov., sp. nov., an anaerobic, moderately thermophilic, syntrophic alcohol- and lactate-degrading bacterium isolated from thermophilic digested sludges. Int. J. Syst. Evol. Microbiol. 2006, 56, 1621-1629.

23. Cayol, J.L.; Ollivier, B.; Patel, B.K.C.; Ravot, G.; Magot, M.; Ageron, E.; Grimont, P.A.D.; Garcia, J.L. Description of Thermoanaerobacter brockii subsp. lactiethylicus subsp. nov., isolated from a deep subsurface French oil well, a proposal to reclassify Thermoanaerobacter finnii as Thermoanaerobacter brockii subsp. finnii comb. nov., and an emended description of Thermoanaerobacter brockii. Int. J. Syst. Bacteriol. 1995, 45, 783-789.

24. Cann, I.K.; Stroot, P.G.; Mackie, K.R.; White, B.A.; Mackie, R.I. Characterization of two novel saccharolytic, anaerobic thermophiles, Thermoanaerobacterium polysaccharolyticum sp. nov. and Thermoanaerobacterium zeae sp. nov., and emendation of the genus Thermoanaerobacterium. Int. J. Syst. Evol. Microbiol. 2001, 51, 293-302.

25. Amend, J.P.; Shock, E.L. Energetics of overall metabolic reactions of thermophilic and hyperthermophilic Archaea and Bacteria. FEMS Microbiol. Rev. 2001, 25, 175-243.

26. Tomás, A.F. Optimization of Bioethanol Production from Carbohydrate Rich Wastes by Extreme Thermophilic Microorganisms. Ph.D. Thesis, Technical University of Denmark, Copenhagen, Denmark, 2013.

27. Sveinsdottir, M.; Baldursson, S.R.B.; Orlygsson, J. Ethanol production from monosugars and lignocellulosic biomass by thermophilic bacteria isolated from Icelandic hot springs. Icel. Agric. Sci. 2009, 22, 45-58.

28. Crespo, C.; Pozzo, T.; Karlsson, E.N.; Alvarez, M.P.; Mattiasson, B. Caloramator boliviensis sp. nov., a thermophilic, ethanol-producing bacterium isolated from a hot spring. Int. J. Syst. Evol. Microbiol. 2012, 62, 1679-1686.

29. Euzéby, J.P. List of Bacterial Names with Standing in Nomenclature: A folder available on the Internet. Int. J. Syst. Evol. Microbiol. 1997, 47, 590-592.

30. Parte, A.C. LPSN-List of prokaryotic names with standing in nomenclature. Nucleic Acids Res. 2014, 42, D613-D616.

31. Wiegel, J.; Tanner, R.; Rainey, F.A. An introduction to the family clostridiae. In The Prokaryotes, 3rd ed.; Dworkin, M., Falkow, S., Rosenberg, E., Schleifer, K.-H., Stackebrandt, E., Eds.; Springer: New York, NY, USA, 2006; Part 1, pp. 654-678.

32. Canganella, F.; Wiegel, J. The potential of thermophilic clostridia in biotechnology. In The Clostridia and Biotechnology; Woods, D.R., Ed.; Butterworth-Heinemann: Freepost, UK, 1993; Volume 23, pp. 394-429. 
33. Carreira, L.H.; Ljungdahl, L.G. Production of ethanol from biomass using anaerobic thermophilic bacteria. In Liquid Fuel Developments; Wise, D.L., Ed.; CRC Press: Boca Raton, FL, USA, 1993; pp. 1-28.

34. Nölling, J.; Breton, G.; Omelchenko, M.V.; Makarova, K.S.; Zeng, Q.; Gibson, R.; Lee, H.M.; Dubois, J.; Qiu, D.; Hitti, J.; et al. Genome sequence and comparative analysis of the solvent-producing bacterium Clostridium acetobutylicum. J. Bacteriol. 2001, 183, 4823-4838.

35. Sabathé, F.; Belaich, A.; Soucaille, P. Characterization of the cellulolytic complex (cellulosome) of Clostridium acetobutylicum. FEMS Microbiol. Lett. 2002, 217, 15-22.

36. Han, S.O.; Yukawa, H.; Inui, M.; Doi, R.H. Transcription of Clostridium cellulovorans cellulosomal cellulase and hemicellulase genes. J. Bacteriol. 2003, 185, 2520-2527.

37. Rydzak, T.; Grigoryan, M.; Cunningham, Z.J.; Krokhin, O.V.; Ezzati, P.; Cicek, N.; Levin, D.B.; Wilkins, J.A.; Sparling, R. Insights into electron flux manipulations of fermentation conditions and assessment of protein expression profiles in Clostridium thermocellum. Appl. Microbiol. Biotechnol. 2014, 98, 6497-6510.

38. Collins, M.D.; Lawson, P.A.; Willems, A.; Cordoba, J.J.; Fernandez-Garayzabal, J.; Garcia, P.; Cai, J.; Hippe, H.; Farrow, J.A. The phylogeny of the genus Clostridium: Proposal of five new genera and eleven new species combinations. Int. J. Syst. Evol. Microbiol. 1994, 44, 812-826.

39. Schink, B.; Zeikus, J.G. Clostridium thermosulfurogenes sp. nov, a new thermophile that produces elementar sulfur from thiosulfate. Microbiology 1983, 129, 1145-1158.

40. Lee, Y.-E.; Jain, M.K.; Lee, C.; Lowe, S.E.; Zeikus, J.G. Taxonomic distinction of saccharolytic thermophilic anaerobes: Description of Thermoanaerobacterium xylanolyticum gen. nov., sp. nov., and Thermoanaerobacterium saccharolyticum gen. nov., sp. nov.; reclassification of Thermoanaerobium brockii, Clostridium thermosulfurogenes, and Clostridium thermohydrosulfuricum E100-69 as Thermoanaerobacter brockii comb. nov., Thermoanaerobacterium thermosulfurigenes comb. nov., and Thermoanaerobacter thermohydrosulfuricus comb. nov., respectively; and transfer of Clostridium thermohydrosulfuricum 39E to Thermoanaerobacter ethanolicus. Int. J. Syst. Evol. Microbiol. 1993, 43, 41-51.

41. Kublanov, I.V.; Prokofeva, M.I.; Kostrikina, N.A.; Kolganova, T.V.; Tourova, T.P.; Wiegel, J.; Bonch-Osmolovskaya, E.A. Thermoanaerobacterium aciditolerans sp. nov., a moderate thremoacidophile from a Kamchatka hot spring. Int. J. Syst. Evol. Microbiol. 2007, 57, 260-264.

42. Almarsdottir, A.R.; Sigurbjornsdottir, M.A.; Orlygsson, J. Effects of various factors on ethanol yields from lignocellulosic biomass by Thermoanaerobacterium $\mathrm{AK}_{17}$. Biotechnol. Bioeng. 2012, 109, 686-694.

43. Crespo, R.E.; Badshah, M.; Alvarez, M.T.; Mattiasson, B. Ethanol production by continuous fermentation of D-(+)-cellobiose, D-(+)-xylose and sugarcane bagasse hydrolysate using the thermoanaerobe Caloramator boliviensis. Bioresour. Technol. 2012, 103, 186-191.

44. Balusu, R.; Paduru, R.M.R.; Seenyya, G.; Reddy, G. Production of ethanol from cellulosic biomass by Clostridium thermocellum SS19 in submerged fermentation: Screening of nutrients using Plackett-Burman desing. Appl. Biochem. Biotechnol. 2004, 117, 133-141.

45. Rani, K.S.; Seenayya, G. High ethanol tolerance of new isolates of Clostridium thermocellum strains SS21 and SS22. World J. Microbiol. Biotechnol. 1999, 15, 173-178. 
46. Roberts, S.B.; Gowen, C.M.; Brooks, J.P.; Fong, S.S. Genome-scale metabolic analysis of Clostridium thermocellum for bioethanol production. BMC Syst. Biol. 2010, 4, doi:10.1186/1752-0509-4-31.

47. Tyurin, M.; Desai, S.; Lynd, L.R. Electrotransformation of Clostridium thermocellum. Appl. Environ. Microbiol. 2012, 70, 883-890.

48. Orlygsson, J. Ethanol production from biomass by a moderate thermophile, Clostridium AK1. Icel. Agric. Sci. 2012, 25, 25-35.

49. Shaw, A.J.; Podkaminer, K.K.; Desai, S.G.; Bardsley, J.S.; Rogers, S.R.; Thorne, P.G.; Hogsett, D.A.; Lynd, L.R. Metabolic engineering of a thermophilic bacterium to produce ethanol at high yield. Proc. Natl. Acad. Sci. USA 2008, 105, 13769-13774.

50. Koskinen, P.E.P.; Beck, S.R.; Orlygsson, J.; Puhakka, J.A. Ethanol and hydrogen production by two thermophilic, anaerobic bacteria isolated from Icelandic geothermal areas. Biotechnol. Bioeng. 2008, 101, 679-690.

51. Hild, H.M.; Stuckey, D.C.; Leak, D.J. Effect of nutrient limitation on product formation during continuous fermentation of xylose with Thermoanaerobacter ethanolicus JW200 $\mathrm{Fe}(7)$. Appl. Microbiol. Biotechnol. 2003, 60, 679-686.

52. Lacis, L.S.; Lawford, H.G. Ethanol-production from xylose by Thermoanaerobacter ethanolicus in batch and continuous culture. Arch. Microbiol. 1988, 150, 48-55.

53. Lovitt, R.W.; Shen, G.J.; Zeikus, J.G. Ethanol production by thermophilic bacteria: Biochemical basis for ethanol and hydrogen tolerance in Clostridium thermohydrosulfuricum. J. Bacteriol. 1988, 170, 2809-2815.

54. Zeikus, J. Microbiology of methanogenesis in thermal, volcanic environments. J. Bacteriol. 1980, 143, 432-440.

55. Yao, S.; Mikkelsen, M.J. Metabolic engineering to improve ethanol production in Thermoanaerobacter mathranii. Appl. Microbiol. Biotechnol. 2010, 88, 199-208.

56. Tomás, A.F.; Karakashev, D.; Angelidaki, I. Thermoanaerobacter pentosaceus sp. nov., an anaerobic, extreme thermophilic, high ethanol-yielding bacterium isolated from household waste. Int. J. Syst. Evol. Microbiol. 2013, 63, 2396-2404.

57. Tomás, A.F.; Karagöz, P.; Karakashev, D.; Angelidaki, I. Extreme thermophilic ethanol production from rapeseed straw: Using the newly isolated Thermoanaerobacter pentosaceus and combining it with Saccharomyces cerevisiae in a two-step process. Biotechnol. Bioeng. 2013, 110, 1574-1582.

58. Brynjarsdottir, H.; Wawiernia, B.; Orlygsson, J. Ethanol production from sugars and complex biomass by Thermoanaerobacter $\mathrm{AK}_{5}$ : The effect of electron-scavenging systems on end-product formation. Energy Fuels 2012, 26, 4568-4574.

59. Lee, Y.-J.; Dashti, M.; Prange, A.; Rainey, F.A.; Rohde, M.; Whitman, W.B.; Wiegel, J. Thermoanerobacter sulfurigignens sp. nov., an anaerobic thermophilic bacerium that reduces $1 \mathrm{M}$ thiosulfate to elemental sulfur and tolerates $90 \mathrm{mM}$ sulfite. Int. J. Syst. Evol. Microbiol. 2007, 57, 1429-1434.

60. Georgieva, T.I.; Ahring, B.K. Evaluation of continuous ethanol fermentation of dilute-acid corn stover hydrolysate using thermophilic anaerobic bacterium Thermoanaerobacter BG1L1. Appl. Microbiol. Biotechnol. 2007, 77, 61-68. 
61. Georgieva, T.I.; Mikkelsen, M.J.; Ahring, B.K. High ethanol tolerance of the thermophilic anaerobic ethanol producer Thermoanaerobacter BG1L1. Cent. Eur. J. Biol. 2007, 2, 364-377.

62. Georgieva, T.I.; Skiadas, I.V.; Ahring, B.K. Effect of temperature on ethanol tolerance of a thermophilic anaerobic ethanol producer Thermoanaerobacter A10: Modeling and simulation. Biotechnol. Bioeng. 2007, 98, 1161-1170.

63. Lacis, L.S.; Lawford, H.G. Effect of growth rate on ethanol production by T. ethanolicus in glucose or xylose limited continuous culture. Biotechnol. Lett. 1988, 10, 603-608.

64. Lacis, L.S.; Lawford, H.G. Analysis of the variation in ethanol yield from glucose or xylose with continuously grown Thermoanaerobacter ethanolicus. Appl. Biochem. Biotechnol. 1989, 20-21, 479-490.

65. Lacis, L.S.; Lawford, H.G. Thermoanaerobacter ethanolicus growth and product yield from elevated levels of xylose or glucose in continuous cultures. Appl. Environ. Microbiol. 1991, 57, 579-585.

66. Lamed, R.; Zeikus, J.G. Ethanol-production by thermophilic bacteria: Relationship between fermentation product yields of and catabolic enzyme-activities in Clostridium thermocellum and Thermoanaerobium brockii. J. Bacteriol. 1980, 144, 569-578.

67. Lamed, R.; Zeikus, J.G. Glucose fermentation pathway of Thermoanaerobium brockii. J. Bacteriol. 1980, 141, 1251-1257.

68. Scully, S.M.; Orlygsson, J. Branched-chain alcohol formation from branched-chain amino acids by Thermoanaerobacter brockii and Thermoanaerobacter yonseiensis. Anaerobe 2014, 30, 82-84.

69. Svetlitchnyi, V.A.; Kensch, O.; Falkenhan, D.A.; Korseska, S.G.; Lippert, N.; Prinz, M.; Sassi, J.; Schickor, A.; Curvers, S. Single-step ethanol production from lignocellulose using novel extremely thermophilic bacteria. Biotechnol. Biofuels 2013, 6, doi:10.1186/1754-6834-6-31.

70. Cripps, R.E.; Eley, K.; Leak, D.J.; Rudd, B.; Taylor, M.; Todd, M.; Boakes, S.; Martin, S.; Atkinson, T. Metabolic engineering of Geobacillus thermoglucosidasius for high yield ethanol production. Metab. Eng. 2009, 11, 398-408.

71. Zambare, V.; Bhalla, A.; Muthukumarappan, K.; Sani, R.K.; Christopher, L. Bioprocessing of agricultural waste to ethanol utilizing a cellulolytic extremophile. Extremophiles 2011, 15, 611-618.

72. Weimer, P.J. Use of thermophiles for production of fuels and chemicals. In Thermophiles: General, Molecular and Applied Microbiology; Brock, T.D., Ed.; John Wiley \& Sons: New York, NY, USA, 1986; pp. 217-255.

73. Fardeau, M.L.; Faudon, C.; Cayol, J.L.; Magot, M.; Patel, B.K.C.; Ollivier, B. Effect of thiosulphate as electron acceptor on glucose and xylose oxidation by Thermoanaerobacter finnii and a Thermoanaerobacter sp. isolated from oil field water. Res. Microbiol. 1996, 147, 159-165.

74. Jones, P. Improving fermentative biomass-derived $\mathrm{H}_{2}$-production by engineered microbial metabolism. Int. J. Hydrog. Energy 2008, 33, 5122-5130.

75. Hallenbeck, P.C. Fermentative hydrogen production: Principles, progress and prognosis. Int. J. Hydrog. Energy 2009, 34, 7379-7389.

76. Cord-Ruwisch, R.; Seitz, H.J.; Conrad, R. The capacity of hydrogenotrophic anaerobic bacteria for compete for traces of hydrogen depends on the redox potential of the terminal electron-acceptor. Arch. Microbiol. 1988, 149, 350-357. 
77. Fardeau, M.L.; Patel, B.K.C.; Magot, M.; Ollivier, B. Utilization of serine, leucine, isoleucine and valine by Thermoanerobacter brockii in the presence of thiosulfate or Methanobacterium sp. as electron acceptors. Anaerobe 1997, 3, 405-410.

78. Tomas, A.F.; Karakashev, D.; Angelidaki, I. Effect of xylose and nutrients concentrations on ethanol production by newly isolated extreme thermophilic bacterium. Water Sci. Technol. 2011, 64, 341-347.

79. Lovitt, R.W.; Longin, R.; Zeikus, J.G. Ethanol production by thermophilic bacteria: Physiological comparison of solvent effects on parent and alcohol-tolerant strains of Clostridium thermohydrosulfuricum. Appl. Environ. Microbiol. 1984, 48, 171-177.

80. Wang, D.I.C.; Avgerinos, G.C.; Biocic, I.; Wang, S.D.; Fang, H.Y. Ethanol from cellulosic biomass [and discussion]. Philos. Trans. R. Soc. Lond. Ser. B 1983, 300, 323-333.

81. Klapatch, T.R.; Hogsett, D.A.L.; Baskaran, S.; Pal, S.; Lynd, L.R. Organism development and characterization for ethanol production using thermophilic bacteria. Appl. Biochem. Biotechnol. 1994, 45-46, 209-223.

82. Baskaran, S.; Ahn, H.J.; Lynd, L.R. Investigation of the ethanol tolerance of Clostridium thermosaccharolyticum in continuous culture. Biotechnol. Progress. 1995, 11, 276-281.

83. Carreira, L.H.; Wiegel, J.; Ljungdahl, L.G. Production of ethanol from bio-polymers by anaerobic, thermophilic, and extreme thermophilic bacteria. I. Regulation of carbohydrate utilization in mutants of Thermoanaerobacter ethanolicus. In Proceedings of the 5th Symposium on Biotechnology for Fuels and Chemicals, Gatlinburg, TN, USA, 10-13 May 1983; Volume 13, pp. 183-191.

84. Herrero, A.A.; Gomez, R.F. Development of ethanol tolerance in Clostridium thermocellum: Effect of growth temperature. Appl. Environ. Microbiol. 1980, 40, 571-577.

85. Timmons, M.D.; Knutson, B.L.; Nokes, S.E.; Strobel, H.J.; Lynn, B.C. Analysis of composition and structure of Clostridium thermocellum membranes from wild-type and ethanol-adapted strains. Appl. Microbiol. Biotechnol. 2009, 82, 929-939.

86. Ahring, B.K.; Jensen, K.; Nielsen, P.; Bjerre, A.B.; Schmidt, A.S. Pretreatment of wheat straw and conversion of xylose and xylan to ethanol by thermophilic anaerobic bacteria. Bioresour. Technol. 1996, 58, 107-113.

87. Ahring, B.K.; Licht, D.; Schmidt, A.S.; Sommer, P.; Thomsen, A.B. Production of ethanol from wet oxidised wheat straw by Thermoanaerobacter mathranii. Bioresour. Technol. 1999, 68, 3-9.

88. Zhao, C.; O-Thong, S.; Karakashev, D.; Angelidaki, I.; Lu, W.; Wang, H. High yield simultaneus hydrogen and ethanol production under extreme-thermophilic $\left(70{ }^{\circ} \mathrm{C}\right)$ mixed culture environment. Int. J. Hydrog. Energy 2009, 34, 5657-5665.

89. Wiegel, J.; Carreira, L.H.; Mothershed, C.P.; Puls, J. Production of ethanol from bio-polymers by anaerobic, thermophilic, and extreme thermophilic bacteria. II. Thermoanaerobacter ethanolicus JW200 and its mutants in batch cultures and resting cell experiments. In Proceedings of the 5th Symposium on Biotechnology for Fuels and Chemicals, Gatlinburg, TN, USA, 10-13 May 1983; Volume 13, pp. 193-205.

90. Rani, K.S.; Swamy, M.V.; Seenayya, G. Production of ethanol from various pure and natural cellulosic biomass by Clostridium thermocellum strains SS21 and SS22. Process Biochem. 1988, $33,435-440$. 
91. Lin, C.W.; Wu, C.H.; Tran, D.T.; Shih, M.C.; Li, W.H.; Wu, C.F. Mixed culture fermentation from lignocellulosic materials using thermophilic lignocellulose-degrading anaerobes. Process Biochem. 2010, 46, 489-493.

92. Georgieva, T.I.; Mikkelsen, M.J.; Ahring, B.K. Ethanol production from wet-exploded wheat straw hydrolysate by thermophilic anaerobic bacterium Thermoanaerobacter BG1L1 in a continuous immobilized reactor. Appl. Biochem. Biotechnol. 2008, 145, 99-110.

93. Lynd, L.R.; Grethlein, H.E.; Wolkin, R.H. Fermentation of cellulosic substrates in batch and continuous culture by Clostridium thermocellum. Appl. Environ. Microbiol. 1989, 55, 3131-3139.

94. Ahn, H.J.; Lynd, L.R. Cellulose degradation and ethanol production by thermophilic bacteria using mineral growth medium. Appl. Biochem. Biotechnol. 1996, 57, 599-604.

95. Rani, K.S.; Swamy, M.V.; Seenayya, G. Increased ethanol production by metabolic modulation of cellulose fermentation in Clostridium thermocellum. Biotechnol. Lett. 1997, 19, 819-823.

96. $\mathrm{Xu}, \mathrm{L}$;; Tschirner, U. Immobilized anaerobic fermentation for bio-fuel production by Clostridium co-culture. Bioprocess Biosys. Eng. 2014, 37, 1551-1559.

97. Klinke, H.B.; Thomsen, A.B.; Ahring, B.K. Potential inhibitors from wet oxidation of wheat straw and their effect on growth and ethanol production by Thermoanaerobacter mathranii. Appl. Microbiol. Biotechnol. 2001, 57, 631-638.

98. Avci, A.; Donmez, S. Effect of zinc on ethanol production by two Thermoanaerobacter strains. Process Biochem. 2006, 41, 984-989.

99. Lynd, L.R.; Weimer, P.J.; van Zyl, W.H.; Pretorius, I.S. Microbial cellulose utilization fundamentals and biotechnology. Microbiol. Mol. Biol. Rev. 2002, 66, 506-577.

100. He, Q.; Lokken, P.M.; Chen, S.; Zhou, J. Characterization of the impact of acetate and lactate on ethanolic fermentation by Thermoanaerobacter ethanolicus. Bioresour. Technol. 2009, 100, 5955-5965.

101. Shao, X.; Raman, B.; Zhu, M.; Mielenz, J.R.; Brown, S.D.; Guss, A.M.; Lynd, L.R. Mutant selection and phenotypic and genetic characterization of ethanol-tolerant strains of Clostridium thermocellum. Appl. Microbiol. Biotechnol. 2011, 92, 641-652.

102. Sittijunda, S.; Tomas, A.F.; Reungsang, A.; O-Thong, S.; Angelidaki, I. Ethanol production from glucose and xylose by immobiliezed Thermoanaerobacter pentosaceus at $70{ }^{\circ} \mathrm{C}$ in an up-flow anaerobic sludge blanket (UASB) reactor. Bioresour. Technol. 2013, 143, 598-607.

103. Shaw, A.J.; Hogsett, D.A.; Lynd, L.R. Natural competence in Thermoanaerobacter and Thermoanaerobacterium species. Appl. Environ. Microbiol. 2010, 76, 4713-4719.

104. Shaw, A.J.; Covalla, S.F.; Miller, B.B.; Firliet, B.T.; Hogsett, D.; Herring, C.D. Urease expression in a Thermoanaerobacterium saccharolyticum ethanologen allows high titer ethanol production. Metab. Eng. 2012, 14, 528-532.

105. Desai, S.G.; Guerinot, M.L.; Lynd, L.R. Cloning of L-lactate dehydrogenase and elimination of lactic acid production via gene knockout in Thermoanaerobacterium saccharolyticum JW/SL-YS485. Appl. Microbiol. Biotechnol. 2004, 65, 600-605.

106. Argyros, D.A.; Tripathi, S.A.; Barrett, T.F.; Rogers, S.R.; Feinberg, L.F.; Olson, D.G.; Foden, J.M.; Miller, B.B.; Lynd, L.R.; Hogsett, D.A.; et al. High ethanol titers from cellulose by using metabolically engineered thermophilic, anaerobic microbes. Appl. Environ. Microbiol. 2011, 77, 8288-8294. 
107. Tyurin, M.V.; Lynd, L.R.; Wiegel, J. 13 Gene transfer systems for obligately anaerobic thermophilic bacteria. Methods Microbiol. 2006, 35, 309-330.

108. Mai, V.; Lorenz, W.W.; Wiegel, J. Transformation of Thermoanaerobacterium sp. strain JW/SL-YS485 with plasmid pIKM1 conferring kanamycin resistance. FEMS Microbiol. Lett. 1997, 148, 163-167.

109. Mai, V.; Wiegel, J. Advances in development of genetic system for Thermoanaerobacterium spp.: Expression of genes encoding hydrolytic enzymes, development of second shuttle vector, and integration of genes into the chromosome. Appl. Environ. Microbiol. 2000, 66, 4817-4821.

110. Shaw, A.J.; Hogsett, D.A.; Lynd, L.R. Identification of the [FeFe]-hydrogenase responsible for hydrogen generation in Thermoanaerobacterium saccharolyticum and demonstration of increased ethanol yield via hydrogenase knockout. J. Bacteriol. 2009, 191, 6457-6464.

111. Tripathi, S.A.; Olson, D.G.; Argyros, D.A.; Miller, B.B.; Barrett, T.F.; Murphy, D.M.; Mccool, J.D.; Warner, A.K.; Rajgarhia, V.B.; Lynd, L.R.; et al. Development of pyrF-based genetic system for targeted gene deletion in Clostridium thermocellum and creation of a pta mutant. Appl. Environ. Microbiol. 2010, 76, 6591-6599.

112. Biswas, R.; Prabhu, S.; Lynd, L.R.; Guss, A.M. Increase in ethanol yield via elimination of lactate production in an ethanol-tolerant mutant of Clostridium thermocellum. PLoS One 2014, 9 , doi:10.1371/journal.pone.0086389.

113. Sommer, P.; Georgieva, T.; Ahring, B.K. Potential for using thermophilic anaerobic bacteria for bioethanol production from hemicellulose. Biochem. Soc. Trans. 2004, 32, 283-289.

114. Yao, S.; Mikkelsen, M.J. Identification and overexpression of a bifunctional aldehyde/alcohol dehydrogenase responsible for ethanol production in Thermoanaerobacter mathranii. J. Mol. Microbiol. Biotechnol. 2010, 19, 123-133.

115. Van Zyl, L.J.; Taylor, M.P.; Eley, K.; Tuffin, M.; Cowan, D.A. Engineering pyruvate decarboxylase-mediated ethanol production in the thermophilic host Geobacillus thermoglucosidasius. Appl. Microbiol. Biotechnol. 2014, 98, 1247-1259.

116. Mosier, N.; Wyman, C.; Dale, B.; Elander, R.; Lee, Y.Y.; Holtzapple, M.; Landisch, M. Features of promising technologies for pretreatment of lignocellulosic biomass. Bioresour. Technol. 2005, 96, 673-686.

117. Zhu, J.Y.; Pan, X.; Zalesny, R.S. Pretreatment of woody biomass for biofuel production: Energy efficiency, technologies and recalcitrance. Appl. Microbiol. Biotechnol. 2010, 87, 847-857.

118. Chiaramonti, D.; Prussi, M.; Ferrero, S.; Oriani, L.; Ottonello, P.; Torre, P.; Cherchi, F. Review of pretreatment processes for lignocellulosic ethanol production, and development of an innovative method. Biomass Bioenergy 2012, 46, 25-35.

119. Menon, V.; Rao, M. Trends in bioconversion of lignocellulose: Biofuels, platform chemicals \& biorefinery concept. Prog. Energy Combust. Sci. 2012, 38, 522-550.

120. Talebnia, F.; Karakashev, D.; Angelidaki, I. Production of bioethanol from wheat straw: An overview on pretreatment, hydrolysis and fermentation. Bioresour. Technol. 2010, 101, 4744-4753.

121. Elleuche, S.; Schröder, C.; Sahm, K.; Antranikian, G. Extremozymes-Biocatalysts with unique properties from extremophilic microorganisms. Curr. Opin. Biotechnol. 2014, 29, 116-123. 
122. Bhalla, A.; Bansal, N.; Kumar, S.; Bischoff, K.M.; Sani, R.K. Improved lignocellulose conversion to biofuels with thermophilic bacteria and thermostable enzymes. Bioresour. Technol. 2013, 128, 751-759.

123. Podkaminer, K.K.; Kenealy, W.R.; Herring, C.D.; Hogsett, D.A.; Lynd, L.R. Ethanol and anaerobic conditions reversibly inhibit commercial cellulase activity in thermophilic simultaneous saccharification and fermentation (tSSF). Biotechnol. Biofuels 2012, 5, doi:10.1186/1754-6834-5-43.

124. Balat, M.; Balat, H.; Öz, C. Progress in bioethanol processing. Prog. Energy Combust. Sci. 2008, 34, 551-573.

125. Sun, Y.; Cheng, J. Hydrolysis of lignocellulosic materials for ethanol production: A review. Bioresour. Technol. 2002, 83, 1-11.

126. Babiker, M.A.A.; Hosida, H.; Ano, A.; Nonklang, S.; Akada, R. High-temperature fermentation: How can processes for ethanol production at high temperatures become superior to the traditional process using mesophilic yeast? Appl. Microbiol. Biotechnol. 2010, 85, 861-867.

127. Vohra, M.; Manwar, J.; Manmode, R.; Padgilwar, S.; Patil, S. Bioethanol production: Feedstock and current technologies. J. Environ. Chem. Eng. 2014, 2, 573-584.

128. Lynd, L.R. Overview and evaluation of fuel ethanol from cellulosic biomass: Technology, economics, the environment, and policy. Annu. Rev. Energy Environ. 1996, 21, 403-465.

129. Lynd, L.R.; van Zyl, W.H.; McBride, J.E.; Laser, M. Consolidated bioprocessing of cellulosic biomass: An update. Curr. Opin. Biotechnol. 2005, 16, 577-583.

130. Xu, Q.; Singh, A.; Himmel, M.E. Perspectives and new directions for the production of bioethanol using consolidated bioprocessing of lignocellulose. Curr. Opin. Biotechnol. 2009, 20, 364-371.

131. Amore, A.; Faraco, V. Potential of fungi as category I Consolidated BioProcessing organisms for cellulosic ethanol production. Renew. Sustain. Energy Rev. 2012, 16, 3286-3301.

132. Olson, D.G.; McBride, J.E.; Shaw, A.J.; Lynd, L.R. Recent progress in consolidated bioprocessing. Curr. Opin. Biotechnol. 2012, 23, 396-405.

133. Kumar, R.; Singh, S.; Singh, O.V. Bioconversion of lignocellulosic biomass: Biochemical and molecular perspectives. J. Ind. Microbiol. Biotechnol. 2008, 35, 377-391.

134. Zaldivar, J.; Nielsen, J.; Olsson, L. Fuel ethanol production from lignocellulose: A challenge for metabolic engineering and process integration. Appl. Microbiol. Biotechnol. 2001, 56, 17-34.

135. Cherry, J.R.; Fidantsef, A.L. Directed evolution of industrial enzymes: An update. Curr. Opin. Biotechnol. 2003, 14, 438-443.

(C) 2014 by the authors; licensee MDPI, Basel, Switzerland. This article is an open access article distributed under the terms and conditions of the Creative Commons Attribution license (http://creativecommons.org/licenses/by/4.0/). 